
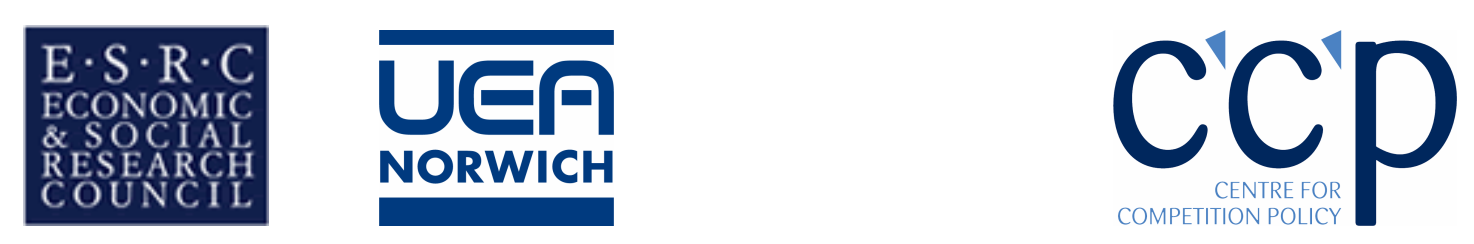

\title{
Potential Impact of Electricity Reforms on Turkish Households
}

by

\author{
Necmiddin Bagdadioglu
}

Department of Public Finance, Hacettepe University

$\&$

Alparslan Basaran

Department of Public Finance, Hacettepe University

\&

Catherine Waddams Price

ESRC Centre for Competition Policy and Norwich Business School, University of East Anglia

\section{CCP Working Paper 07-8}

\begin{abstract}
This paper analyses the potential effect of electricity reform on different households, using a series of potential scenarios for price changes, and consumption information from the 2003 Turkish Household Expenditure Survey. Turkey is emerging as a regional energy market, hub, and transit country between Europe and Asia, and has been reforming her energy sector in line with EU Energy Acquis since 2001. Introducing a cost reflective tariff is an essential component of Turkish electricity reform. Yet, this tariff structure might create real hardship for, and thus strong opposition from, some households, which might not be compensated through the rather underdeveloped Turkish social security system. Perhaps to avoid the possible political costs of this before the general election of November 2007, the Turkish Government disregarded the sector regulator EMRA's insistence, and postponed pursuing such tariff for at least five years. Identifying these households, however, helps to anticipate opposition, and perhaps to mitigate it partially through compensation schemes. This might also facilitate Turkey's integration with the Energy Community of South East Europe created in 2005. To explore the likely effect of tariff changes on various groups of households we apply six scenarios. Firstly, we analyse the likely impact of EMRA's proposal of reflecting large regional variation in technical and non-technical losses. We also consider the effect of a potential efficiency saving from the proposed merger of distribution companies. Then, we explore the potential outcome of raising the currently low ratio of residential to industrial tariffs to OECD average. Furthermore, we study the effect of reducing the rather high level of taxes on households. Lastly, we examine the likely consequence of changing the present flat rate prices per kilowatt hour to a tariff which reflects more accurately the pattern of consumer-related and consumption-related costs.
\end{abstract}

April 2007 
JEL Classification Codes: D10, L94, Q48

Keywords: Household survey, electric utilities, government policy

\section{Acknowledgements:}

We gratefully acknowledge the financial assistance of the European Union, while Necmiddin Bagdadioglu was a visiting researcher, under the 2005/06 Jean Monnet Scholarship programme, at the ESRC Centre for Competition Policy at the University of East Anglia; and of the Economic and Social Research Council. We are grateful for comments received from Alper Basaran, Morten Hviid, Michael Pollitt, and participants in the Second International Conference on Business, Economics and Management at Izmir, Turkey, in June 2006. The authors remain responsible for the content of this document, which cannot be regarded as reflecting the views of the funders.

\section{Contact details:}

Corresponding author: Catherine Waddams Price, ESRC Centre for Competition Policy, University of East Anglia, Norwich, NR4 7TJ, UK c.waddams@uea.ac.uk 


\section{Turkish residential energy tariffs and potential reform}

Energy reforms are a crucial component of the package of negotiations which Turkey is undertaking to enter the European Union. Several fundamental reforms are in various stages of implementation in electricity (Cetin and Oguz, 2006, Atiyas and Dutz, 2005, Ozkivrak, 2005, Hepbasli, 2005). One aspect of such reforms is that tariffs should become more cost reflective, and we examine the effect of several such potential changes on households in Turkey, using information from the Turkish Household Expenditure Survey (THES) for 2003. It thus complements the extensive study of electricity affordability in neighbouring south east European countries, who are also participants in plans for a local electricity market (EBRD, 2003). However unlike that study it considers several different scenarios, each of which address the mismatch between current tariffs and long run marginal costs in rather different ways. We use these as illustrative examples of potential changes, while recognising that our list is not exhaustive and that reform may bring other changes as part of the preparation for EU accession.

Most of the changes are for tariffs to reflect current cost levels or structures, but we include one proposal which anticipates potential cost reductions which are passed on to consumers. Some of the reforms which we consider would raise prices substantially (up to $50 \%$ ) for some households. While this is less than in some transition countries (Langouw et al, 2004, report electricity prices rising sevenfold in Hungary over a six year period), in a country where income levels are low and social security systems poorly developed, such effects are important for two reasons. Political opposition to reforms is likely to be greatest from those who may lose as a result. One such group is employees, who may fear that reform will reduce staffing levels: in the UK electricity industry reform resulted in just over $20 \%$ reduction in costs, largely from staffing (Newbery and Pollit, 1997). But substantial political opposition is also likely from households who expect substantial increases in their electricity bills, particularly if they are grouped in one region of the country. Knowing which groups might be adversely affected helps to anticipate opposition, and perhaps to mitigate it partially through compensation schemes.

Equally important for a country such as Turkey, large changes in tariffs might create real hardship for some households, which would not be compensated through the (rather undeveloped) social security system (World Bank and TSIS, 2005). Identifying these households can enable authorities to anticipate and alleviate some of the worst of these difficulties. We focus on the average effects for a particular household group or region, and in particular the percentage of income which any changes are likely to constitute. How households are affected depends on where they live and how much electricity they use.

Turkey's economy is more market-oriented than that of many of its formerly centrally planned neighbours, so the effect of electricity reform is likely to have a significant effect on households, independent of other changes in the economy. We therefore focus on this single market, in contrast to studies of more general effects of transition (for example Newbery, 1995; Pudney et al, 2001; Langouw et al, 2004). 
Our paper uses household level data from the Turkish Household Expenditure Survey (THES) to identify the effects on different households and groups. It calculates potential welfare changes for different household and income groups, based on the methodology of Waddams Price and Hancock (1998), and that used in several studies of Latin American countries in Ugaz and Waddams Price (2003). Our analysis is complicated by missing data for electricity expenditure by more than a quarter of the households. However only seven out of more than twenty-five thousand respondents reported no electricity connection, and the electrification rate for Turkey was already $95 \%$ in 2000 (IEA, 2002). This high connection rate means that extension of the network is not an objective of electricity reform (though increasing its quality may be, given a high level of losses) and we interpret these figures as non-technical losses, the subject of one of the scenarios in our analysis.

Several characteristics of Turkey's current residential tariffs do not at present reflect costs, and we analyse three aspects. The first is the pattern of regional tariffs, where we analyse the effect of a reform proposed by the energy regulator Energy Market Regulatory Agency (EMRA) but postponed by the government, and contrast this with the reform that is being implemented. For the last few years a national tariff system is imposed which does not reflect the large regional variation in technical losses, but does include a small discount $(0.65 \%)$ for a group of 'priority' provinces. EMRA's proposal to differentiate tariffs provincially on the basis of losses has been deferred for at least five years; instead a single tariff is to be introduced, abolishing the distinction between priority and non-priority provinces. We analyse the effect of both of these regional changes on different household groups, assuming the reforms to be revenue-neutral. Secondly we consider potential changes in the level of residential tariffs. We also consider the effect of a potential efficiency saving from the merger of distribution companies, as an example of how sector reform might affect costs and therefore tariffs. This would lower prices in those provinces where there is currently greatest potential for increased efficiency, and has the opposite (directional) effect to those of the EMRA proposals.

The current ratio of residential to industrial tariffs is low by OECD standards, and rectification would increase residential tariffs. Conversely a number of taxes are presently levied on electricity consumers, and their removal would lower price levels. We consider the effects of these opposite (and broadly equal) changes. Lastly, we analyse the potential effect of changing the present flat rate prices per kilowatt hour to a tariff which reflects more accurately the pattern of consumer-related and consumption-related costs.

The effect of any of these changes on any one household depends on their pattern of electricity consumption. Before presenting our analysis we therefore first present the profile of household energy consumption in Turkey. In section 3 we discuss the reforms which we have identified and their effects on tariff levels and structures, and in section 4 explain the methodology we use for calculating the effect of these changes in each scenario. Section 5 presents the results, and section 6 concludes. 


\section{Household energy consumption in Turkey}

Electricity is mainly used in Turkish households for lighting, power and air conditioning, with little use for heating, which is mainly met by burning oil, coal, or natural gas (in larger cities). The household characteristics which we consider are household disposable income (including benefits in kind and state benefits), educational attainment of the respondent, household structure, ownership and type of dwelling, affiliation with social security systems, and province. These household characteristics are derived from the THES. We focus on income levels, social security systems and provinces, and these results are shown in the tables below, which describe the average household electricity expenditure and its standard deviation for each category of household, and the average proportion of household income spent on electricity for each of these categories. "The other categories are reported in the appendix.

More directly relevant for our purposes, for 7010 of the 25764 households questioned, electricity expenditure is missing from the survey. We discuss this further at the end of this section. So far as possible we have related our analysis to the full sample. In particular we have defined income deciles with respect to the full sample of 25764, for which we have income figures. In order to identify the tariffs (and therefore the consumption) for each household, we excluded four provinces ${ }^{2}$ where tariffs could not be uniquely determined. Our analysis on energy expenditure itself therefore consists of the spending patterns of the 16385 households for whom non-zero energy expenditure is reported and tariffs are known. The likely effect of the reforms on the other households, though it is difficult to calculate quantitatively, is discussed in qualitative terms in section 5 below. The characteristics of the households who are omitted are shown in the final columns of each table.

Table 1: Average annual household electricity expenditure and income

\begin{tabular}{|c|c|c|c|c|c|c|}
\hline $\begin{array}{l}\text { Income } \\
\text { decile }\end{array}$ & $\begin{array}{c}\text { Average } \\
\text { electricity } \\
\text { expenditure } \\
(1000000 T L)\end{array}$ & $\begin{array}{c}\text { Standard } \\
\text { deviation } \\
(1000000 T L)\end{array}$ & $\begin{array}{l}\text { Expenditure } \\
\text { as a \% of } \\
\text { disposable } \\
\text { income* }\end{array}$ & $\begin{array}{l}\text { number } \\
\text { in } \\
\text { sample }\end{array}$ & $\begin{array}{l}\text { \% for whom } \\
\text { consumption } \\
\text { data missing }\end{array}$ & $\begin{array}{c}\% \text { omitted } \\
\text { because } \\
\text { tariffs } \\
\text { unknown }\end{array}$ \\
\hline $\begin{array}{c}\text { Average/ } \\
\text { total }\end{array}$ & 359 & (274) & 9 & 16385 & 27 & 13 \\
\hline Poorest & 351 & $(0.75)$ & 47 & 1092 & 50 & 16 \\
\hline $2^{\text {nd }}$ & 304 & (5.25) & 24 & 1216 & 35 & 20 \\
\hline $3^{\text {rd }}$ & 311 & (4.91) & 19 & 1541 & 30 & 17 \\
\hline $4^{\text {th }}$ & 324 & (3.62) & 16 & 1575 & 26 & 16 \\
\hline $5^{\text {th }}$ & 320 & (4.13) & 13 & 1580 & 27 & 14 \\
\hline $6^{\text {th }}$ & 332 & $(3.00)$ & 11 & 1730 & 25 & 13 \\
\hline $7^{\text {th }}$ & 342 & (1.93) & 10 & 1838 & 20 & 10 \\
\hline $8^{\text {th }}$ & 363 & $(0.41)$ & 8 & 1820 & 21 & 11 \\
\hline $9^{\text {th }}$ & 392 & (3.64) & 7 & 1884 & 20 & 8 \\
\hline Richest & 503 & (16.72) & 4 & 2009 & 17 & 6 \\
\hline
\end{tabular}

* This column is calculated as the average of the ratio electricity expenditure/disposable income, calculated for each household.

\footnotetext{
${ }^{1}$ Income was normalised for household composition using the OECD standard weighting (World Bank and TSIS, 2005: 118). The formula is as follows: $A E-O E C D=1+$ [number of children under age 14] $\times 0.5+$ ([number of adults] - 1) x 0.75 .

${ }^{2}$ These provinces are Gaziantep, Hatay, Kayseri, and Konya.
} 
We note a typical pattern from the households for which we have consumption data, namely consumption increasing with income in absolute terms, but falling as a proportion of income. Energy consumption also increases with the level of education because education is positively related to income (see table $A 1$ in appendix). The standard deviations in all the tables are low, indicating that this pattern is fairly robust. The poorest group report spending an average of nearly $50 \%$ of their income on electricity. This very high ratio may arise because low income households generate a significant part of their income in kind rather than money, so that any money expenditure appears as a very high proportion of (money) income. Even allowing for such an overestimate, its contrast to the $4 \%$ reported by the richest group is striking. Any increase (or decrease) in general electricity prices will have a much greater impact on low income than on high income households.

Table 2: Average annual household electricity expenditure and social security system

\begin{tabular}{|c|c|c|c|c|c|}
\hline & $\begin{array}{c}\text { Average electricity } \\
\text { expenditure } \\
(1000000 T L)\end{array}$ & $\begin{array}{c}\text { Standard } \\
\text { deviation } \\
(1000000 T L)\end{array}$ & $\begin{array}{l}\text { Expenditure } \\
\text { as \% of } \\
\text { disposable } \\
\text { income } \\
\end{array}$ & $\begin{array}{l}\text { \% for whom } \\
\text { consumption } \\
\text { data missing }\end{array}$ & $\begin{array}{l}\text { \% omitted } \\
\text { because } \\
\text { tariffs } \\
\text { unknown }\end{array}$ \\
\hline Average & 359 & (274) & 9 & 27 & 13 \\
\hline $\begin{array}{c}\text { Social } \\
\text { Security } \\
\text { Institution }\end{array}$ & & & & & \\
\hline Registered & 365 & (255) & 8 & 34 & 9 \\
\hline Not registered & 350 & (302) & 10 & 22 & 10 \\
\hline Green Card & & & & & \\
\hline Has & 313 & (530) & 20 & 39 & 12 \\
\hline Has not & 361 & (262) & 8 & 27 & 9 \\
\hline $\begin{array}{c}\text { State old age } \\
\text { pension }\end{array}$ & & & & & \\
\hline Receiving & 369 & (324) & 13 & 64 & 2 \\
\hline Not receiving & 359 & (272) & 8 & 26 & 9 \\
\hline
\end{tabular}

Social security systems could be used to help alleviate any particularly severe impacts of tariff reform, and table 2 shows energy expenditure according to social security categories. The variations within each category are high, in contrast to the categorisation by income decile, and there is no significant difference in the spending patterns in absolute terms of those who are or are not in any of these categories. However those with a Green $\mathrm{Card}^{3}$ and those receiving an old age pension spend a higher proportion of their (equivalised) income on electricity than households who do not fall into this category.

The reforms which EMRA proposed, which have been postponed for at least five years, were to reflect the difference in technical losses in provincial tariffs. Table 3 shows the provincial pattern of electricity expenditure and the proportion of households with missing values for electricity expenditure in each province.

\footnotetext{
${ }^{3}$ The Green Card system aims to provide protection to low income groups who are not covered otherwise.
} 
Provinces with priority status (where households currently pay $0.65 \%$ less for their electricity) are denoted (P).

Table 3: Average annual household electricity expenditure by province

\begin{tabular}{|c|c|c|c|c|c|c|}
\hline Province name & $\begin{array}{l}2001 \text { GDP per } \\
\text { head } \\
(1000000 T L)^{* *}\end{array}$ & $\begin{array}{c}\text { Average } \\
\text { electricity } \\
\text { expenditure } \\
\text { (1000000TL) }\end{array}$ & $\begin{array}{c}\text { Standard } \\
\text { deviation } \\
\text { (1000000TL) }\end{array}$ & $\begin{array}{c}\text { Expenditure } \\
\text { as } \% \text { of } \\
\text { disposable } \\
\text { income }\end{array}$ & $\begin{array}{l}\text { proportion of } \\
\text { households } \\
\text { for whom } \\
\text { consumption } \\
\text { data missing }\end{array}$ & $\begin{array}{c}\text { proportion } \\
\text { of network } \\
\text { losses, } \\
\% * * *\end{array}$ \\
\hline Average & 1.60 & 359 & $(274)$ & 9 & 27 & $20^{*}$ \\
\hline Izmir & 2.44 & 341 & (280) & 7 & 8 & 8 \\
\hline Balikesir & 1.57 & 407 & (285) & 11 & 39 & 10 \\
\hline Bursa & 2.18 & 327 & $(246)$ & 9 & 27 & 10 \\
\hline Kastamonu $(\mathrm{P})$ & 1.05 & 293 & (236) & 9 & 23 & 10 \\
\hline Zonguldak $(\mathrm{P})$ & 1.65 & 411 & (211) & 12 & 35 & 10 \\
\hline Kirikkale $(P)$ & 1.19 & 345 & (198) & 11 & 31 & 10 \\
\hline Manisa & 1.62 & 302 & (205) & 10 & 37 & 11 \\
\hline Tekirdag & 2.16 & 496 & (432) & 12 & 39 & 13 \\
\hline Kocaeli & 2.85 & 486 & (249) & 11 & 41 & 13 \\
\hline Antalya & 1.53 & 393 & (358) & 8 & 19 & 13 \\
\hline Trabzon $(\mathrm{P})$ & 1.01 & 307 & (173) & 8 & 16 & 13 \\
\hline Aydin & 1.97 & 403 & (295) & 10 & 38 & 14 \\
\hline Malatya $(P)$ & 0.94 & 292 & (162) & 9 & 15 & 14 \\
\hline Ankara & 2.09 & 533 & (323) & 10 & 37 & 14 \\
\hline Samsun $(P)$ & 1.16 & 294 & (184) & 11 & 22 & 16 \\
\hline Istanbul & 2.30 & 367 & (237) & 6 & 7 & 18 \\
\hline Adana & 1.72 & 297 & (255) & 9 & 20 & 22 \\
\hline Erzurum $(\mathrm{P})$ & 0.64 & 324 & (235) & 12 & 16 & 29 \\
\hline Agri $(P)$ & 0.45 & 259 & (137) & 9 & 11 & 40 \\
\hline Sanliurfa $(P)$ & 0.86 & 357 & (330) & 15 & 57 & 59 \\
\hline $\operatorname{Van}(P)$ & 0.42 & 332 & (223) & 12 & 40 & 69 \\
\hline $\operatorname{Mardin}(\mathrm{P})$ & 0.70 & 352 & $(524)$ & 15 & 58 & 70 \\
\hline
\end{tabular}

$\mathrm{P}=$ Province with Priority Status; ${ }^{*}$ weighted average of losses: net electricity delivered; ${ }^{* *}$ Source: State Planning Organisation, http://www.dpt.gov.tr/bgyu/bgr/eg/kbgsyih87.htm (accessed on 29th August 2006); ${ }^{* \star *}$ Derived from Bagdadioglu et al (2007).

Average household electricity use varies considerably between provinces partly because of air conditioning and variations in income. It also varies a great deal within provinces, so that none of the differences in average consumption is statistically significant. Nevertheless some patterns emerge. In Tekirdag, Kocaeli and Zonguldak high absolute spending results in high spending as a proportion of income. In Sanliurfa and Mardin a below average absolute expenditure level nonetheless translates into a very high spend relative to (normalised) income. The priority provinces have on average much lower income than the non-priority provinces, and only three non-priority provinces (Balikesir, Manisa, and Antalya) have lower per capita GDP than the richest priority province (Zonguldak). Since the income of these provinces is particularly low, even small levels of electricity expenditure represent a high proportion of income. We note also that the highest losses are experienced by provinces with low per capita GDP, so reflecting these losses in prices is likely to have a harsh effect on large numbers of low income households. 


\subsection{Consumers reporting zero consumption}

Our tables of energy expenditure omit households reporting no such spending, but those who are using electricity will be affected by any reforms which decrease nontechnical losses. Since most households in Turkey have access to the grid, we interpret these missing values as representing, at least in part, non-technical losses. $99 \%$ of households with this missing value report owning at least one electrically driven appliance, and only $0.1 \%$ report no connection to the grid. These respondents represent $27 \%$ of the full sample, while losses in the system are only $20 \%$, suggesting either that households with missing values have lower than average consumption, or that some values are missing for other, non-loss-related, reasons. However, the final two columns of table 3 show that these 7010 consumers overrepresent provinces with high (technical and non-technical) distribution losses.

Apart from living in lower income provinces with high network losses, we note from the last column of table 1 that the consumers with missing consumption values who are omitted from our main analysis are drawn disproportionately from lower income households. Amongst the lowest decile, $50 \%$ of households reported no expenditure, while the corresponding proportion for the richest decile is only $17 \%$. If reforms include (as is likely eventually, despite the postponement of the EMRA proposals) recovery of non-technical losses, the impact would be disproportionately high for low income households. Similarly, non-reported expenditure is higher amongst those with a Green Card, registered for social security and, very strikingly, for those receiving an old age pension. Any of these households for whom the missing value represents non-technical losses would be hit hard by recovery of such losses. If their incomes are similar to those in the same category who do pay for their electricity, the 'new' charges would also represent a higher than average proportion of their incomes. Clearly also improvement of non-technical losses would have a greater impact in provinces where the level is currently high - and where income tends to be lower. One of the scenarios we consider involves recovering each province's losses from those who currently pay their bills. We discuss in section 6 below the likely impact of these reforms on both the households whose expenditure is recorded data, and on those for whom these values are missing.

This information on the relation between electricity expenditure and household characteristics provides a background for our analysis of potential effects of reform identified in the next section.

\section{Potential effect of reforms}

The major programme of electricity reform being undertaken in Turkey is likely to affect tariffs in a number of ways. It provides incentives to minimise costs, but also to raise prices to the monopoly pricing level. The process of reform itself may release other potential cost savings. If the industry is being subsidised under public ownership, or used to subsidise other activities, the relation between overall revenue and costs will change with ownership, even if the cost levels themselves do not change. Private ownership also introduces incentives for rebalancing prices so that charges to different consumers or groups of consumers are more reflective of the 
costs which they impose on the system, and such incentives are considerably sharpened by the actual or threatened introduction of competition. We consider the effect of a number of potential changes as separate scenarios, so that the impact of each can be separately identified.

Turkey has applied a 'national' system of residential electricity tariffs, with a small discount for priority provinces, mainly more rural provinces in the south and east of the country. In 2003, the year to which our expenditure data relate, the flat rate tariffs were $158000 \mathrm{TL}$ per $\mathrm{kWh}$ for non-priority provinces and 148000TL for priority provinces. The latter are identified with $(P)$ in table 4. This flat national rate does not mirror the very high level and regional differences in distribution losses which we have noted above. The energy regulator, EMRA, proposed that the differences in losses should be reflected in tariffs and our first scenario calculates relative tariffs which would recover from the consumers of each province the total cost of the energy delivered to that province, adjusting the level so that the total revenue recovered is the same. As table 4 shows, this would involve huge increases in tariffs in high loss regions if the base of consumers who pay their bills is not expanded, and it is difficult to see how it could be introduced other than over a number of years. Nevertheless it gives a guide to magnitudes and directions of reflecting this lost energy in tariffs, and is shown in the middle column of table 4. 
Table 4: Possible Regional Tariffs

\begin{tabular}{|l|c|c|}
\hline & \multicolumn{2}{|c|}{ New tariffs (1000 TL per KWh.) } \\
\hline Provinces & Charging for losses (scenario 1) & Reflecting merger gains (scenario 3) \\
\hline İzmir & 131 & 158 \\
\hline Balıkesir & 134 & 156 \\
\hline Bursa & 134 & 156 \\
\hline Kastamonu(P) & 134 & 143 \\
\hline Zonguldak(P) & 134 & 143 \\
\hline Kırıkkale(P) & 134 & 143 \\
\hline Manisa & 136 & 158 \\
\hline Tekirdağ & 139 & 158 \\
\hline Kocaeli & 139 & 158 \\
\hline Antalya & 140 & 155 \\
\hline Trabzon(P) & 140 & 146 \\
\hline Aydın & 140 & 156 \\
\hline Malatya(P) & 140 & 143 \\
\hline Ankara & 141 & 153 \\
\hline Samsun(P) & 144 & 144 \\
\hline İstanbul & 148 & 158 \\
\hline Adana & 156 & 154 \\
\hline Erzurum(P) & 171 & 146 \\
\hline Ağrı(P) & 201 & 146 \\
\hline Şanlıurfa(P) & 297 & 144 \\
\hline Van(P) & 384 & 145 \\
\hline Mardin(P) & 397 & 144 \\
\hline Dogu Karadeniz* & & 146 \\
\hline Kuzeydogu Anadolu & & 146 \\
\hline Guneydogu Anadolu & & 144 \\
\hline Due & & \\
\hline
\end{tabular}

${ }^{*}$ Due to the differences between geographical definitions used in the THES and the merger study of Bagdadioglu et al (2007), we report potential merger gains only for three regions where there is not such a mismatch problem. These regions (and the representative province(s) included in calculations) are Dogu Karadeniz (Trabzon), Kuzeydogu Anadolu (Erzurum and Ağrı), and Guneydogu Anadolu (Sanlırfa and Mardin).

EMRA's proposals to move in a cost reflective direction have been rejected in the short term, and instead a national tariff equalisation programme, to last at least five years, has been instituted (Işik, 2004). This tariff equalisation programme would represent a small move in the cost reflective direction, since many of the provinces with the highest losses are currently designated as priority provinces, and receive the small $(0.65 \%)$ discount in their tariff rates. The priority status reflects lower average income, and one reason to delay the introduction of tariffs which reflect differential regional losses is likely to have been on distributional grounds. As well as our first scenario, which explores the first order effects on different households of the full regional cost reflective tariff reform, we analyse the tariff equalisation programme currently being implemented (as scenario 2), also on a revenue-neutral basis. This would imply a national tariff of $155000 \mathrm{TL}$ per $\mathrm{kWh}$. Since our analysis is of first order effects only, we analyse only aggregate household level responses to such signals, which will be very strong for those provinces where tariffs would reflect the $70 \%$ of electricity currently unaccounted for. While we argue below that households are unlikely to respond rapidly to most tariff changes, such large increases are likely to bring about institutional changes, in particular to reduce non-technical losses, and we discuss the likely implications in section 6 . 
Both these changes are examined assuming that the same revenue is raised from tariffs post-reform as at present, i.e. the changes are revenue-neutral. At the provincial level, we also explore the effect on households of one example of potential efficiency improvement from the reform process as our third scenario. Such potential improvements from the expected merger of the current 82 distribution companies into 21 such groups prior to privatisation were identified in Bagdadioglu et al, 2007 . We explore the effect on households if such improvements were to be realised in each of the new distribution areas and passed on in the form of lower residential tariffs. This is clearly not revenue-neutral, since some provinces gain, and none loses; and it would result in larger tariff reductions in those regions with greatest potential efficiency gains, i.e. who currently experience greatest losses, and which would have been most penalised under the EMRA proposals. In this sense it takes a different position, the current one of (almost) equal tariffs as the base, and rewards improvements from that base. Provinces which currently have low loss rates, and so little room for improvement, might challenge such a baseline.

The level of residential tariffs in Turkey has been almost equal to those charged to industrial consumers, i.e. a much lower proportion of industrial charges than the average in EU, other OECD and South East European countries; the average ratio is $1.7 \%$ in OECD countries (IEA, 2004). Their high relative price has been the cause of complaint from industrialists (Işik, 2004), and opening the energy sector to competition is likely to cause a realignment of these relative prices towards the OECD average, raising the level of residential tariffs across the board. Such a realignment would increase prices in priority provinces to $172000 \mathrm{TL}$ per $\mathrm{kWh}$, and in non-priority provinces to $184000 \mathrm{TL}$, assuming the ratio between these tariffs remains unaltered. Conversely, residential prices incorporate a number of taxes, including VAT at $18 \%$ (other taxes are $1 \%$ for an Energy Fund, $2 \%$ for the Turkish Broadcasting Authority and 5\% Municipality Electricity Consumption Tax). To counteract the effect of rebalancing between residential and industrial tariffs, reform of the industry might include minimising these taxes. Since VAT is already levied on electricity it is unlikely that Turkey could remove it entirely, but it might reduce its level to $5 \%$, the VAT tax levied on UK energy. Like rebalancing between industrial and residential tariffs, this would affect the level of residential tariffs (but in the opposite direction), resulting in tariffs of $122000 \mathrm{TL}$ per $\mathrm{kWh}$ in priority provinces, and $130000 T L$ in non-priority areas. We identify the first order effect of each of these changes in price levels (scenarios 4 and 5), implemented across the country, on different household groups.

Our last scenario considers a change in the structure of tariffs to reflect more accurately the structure of costs of supplying households, namely that a substantial part of costs is consumer rather than consumption related. Such a tariff structure is common in other developed economies. A more common tariff in transition and developing countries is one with the reverse structure, where there is no standing charge and the first units are supplied at a lower price, to help affordability, with higher per unit rates charged for higher levels of consumption. Turkey's flat rate for each unit of electricity consumed represents an interesting compromise between a cost reflective and an affordability-focussed tariff. In deregulated markets, most suppliers charge a fixed amount for each household, independent of the amount of energy consumed (or sometimes higher rates for early units in the UK). Such a fixed 
charge per consumer generally constitutes between ten and twenty percent of an average bill. We have no reason to believe that the cost structure for supplying residential consumers would differ significantly in Turkey, and so we considered the effect of introducing a standing charge at the low end of this range, i.e. $10 \%$ of the average bill, again assuming revenue-neutrality (i.e. this rendered the same total revenue to the electricity suppliers as the current tariffs, at current consumption levels). This constituted our sixth scenario. Such a rebalancing would benefit users of large amounts of electricity, but raise the bills of those who consume little electricity. The prospects of such rebalancing have often caused considerable concern about the prospect of energy reform in other countries, because of its adverse effect on low consumption (and low income) households (see for example Monopolies and Mergers Commission, 1993, in the UK).

Table 5 below summarises the scenarios which we analyse, and their effect on electricity prices.

Table 5: Scenarios and Their Effect on Electricity Prices

\begin{tabular}{|c|c|c|c|}
\hline Scenario & Effect on Price & New tariffs & $\begin{array}{l}\text { Households } \\
\text { Affected }\end{array}$ \\
\hline $\begin{array}{l}\text { 1. Reflect losses } \\
\text { in tariffs at } \\
\text { provincial level }\end{array}$ & Revenue-neutral & See table 4 & All \\
\hline $\begin{array}{l}\text { 2. priority status } \\
\text { removed }\end{array}$ & $\begin{array}{l}\text { Revenue-neutral; } \\
\text { increased by } 0.5 \% \text { for } \\
\text { priority provinces, and } \\
\text { reduced by } 0.2 \% \text { for } \\
\text { other provinces }\end{array}$ & 155000TL per kWh & All \\
\hline $\begin{array}{l}\text { 3. potential } \\
\text { efficiency gains } \\
\text { reflected on } \\
\text { provincial basis }\end{array}$ & $\begin{array}{l}\text { Reduced by around } \\
2 \% \text { on average }\end{array}$ & See table 4 & $\begin{array}{l}\text { All but those living } \\
\text { in Istanbul, } \\
\text { Tekirdag, Balikesir, } \\
\text { Kocaeli, Izmir, and } \\
\text { Sanliurfa }\end{array}$ \\
\hline $\begin{array}{l}\text { 4. ratio of charges } \\
\text { increased to the } \\
\text { OECD average }\end{array}$ & $\begin{array}{l}\text { Average increased by } \\
14 \%\end{array}$ & 155000TL, 184000TL per kWh & All \\
\hline $\begin{array}{l}\text { 5. remove all taxes } \\
\text { except } 5 \% \text { VAT }\end{array}$ & $\begin{array}{l}\text { Average reduced by } \\
18 \%\end{array}$ & 122000TL, 130000TL per kWh & All \\
\hline $\begin{array}{l}\text { 6. } 10 \% \text { standing } \\
\text { charge introduced }\end{array}$ & $\begin{array}{l}\text { Revenue-neutral; low } \\
\text { consumption } \\
\text { households adversely } \\
\text { affected }\end{array}$ & $\begin{array}{l}\text { Fixed charge } 35900000 T L \text { per } \\
\text { year; running rate } 139500 T L \\
\text { per kWh }\end{array}$ & All \\
\hline
\end{tabular}

\section{Effect on Households: Methodology}

We follow the methodology of Hope and Singh (1995) in calculating the change in expenditure of households in each scenario, and, like them, assume a zero elasticity of demand in Turkey for our main analysis. We could find no study of residential electricity demand responsiveness in Turkey, but we have undertaken some sensitivity analysis, using an assumption of an aggregate elasticity of -0.25 , which was assumed for neighbouring countries (except Albania) in EBRD, 2003. Energy elasticity is generally higher for lower income consumers (Baker, Blundell and Micklewright, 1989; Reiss and White, 2005), and we also explore the likely effects of demand elasticities which vary with income. We look only at direct effects of 
residential price rises on residential customers, and not at any secondary effects through, for example, concomitant changes in the prices of industrial electricity and consequently product prices.

Our measure of welfare change for each individual is the difference between the price in 2003 and price after each hypothetical reform, multiplied by our estimate of consumption from the THES data. Figure 1 illustrates this measure and its relation to other standard measures of welfare change. $a b$ is the uncompensated demand curve; ac represents the demand curve compensated to keep the consumer at their original utility level; db is the compensated demand curve at the 2003 post reform utility level using a price reduction scenario for illustration. $p_{1}$ and $p_{2}$ are the (real) prices in 2003 and post reform, and $x_{1}$ and $x_{2}$ are the corresponding demand levels for each household. Following the evidence from table 1 and elsewhere, we assume that electricity is a normal good i.e. that demand increases with income. $x_{1}$ is the quantity that the household consumed when it was questioned for the THES. The THES provides expenditure data, and $x_{1}$ is estimated from knowledge of the tariffs prevailing for each household in that year.

Our measure of expenditure change is then

$$
\Delta W=x_{1}\left(p_{1}-p_{2}\right)
$$

i.e., equivalent to a Laspeyres measure of welfare change.

\section{Figure 1: Measures of Welfare Change}

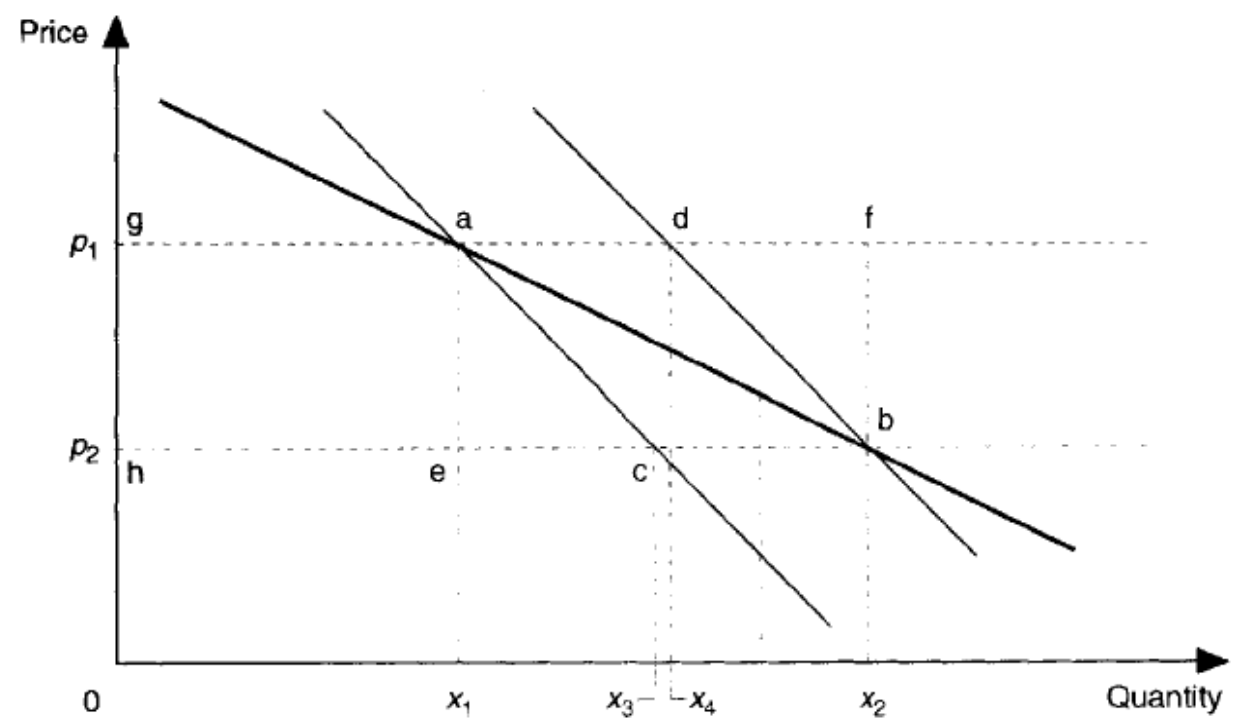

Compensating variation, $C V$, is gaceh, and the equivalent variation, $E V$, is given by gadbceh.

If demand is linear, the Marshallian consumer surplus, $\Delta M$, is

$$
\Delta M=x_{1}\left(p_{1}-p_{2}\right)+\frac{\left(p_{1}-p_{2}\right)}{2}\left(x_{2}-x_{1}\right) \text {, }
$$


i.e.

$$
\Delta M=\frac{\left(p_{1}-p_{2}\right)}{2}\left(x_{1}+x_{2}\right)
$$

Similarly,

$$
C V=\frac{\left(p_{1}-p_{2}\right)}{2}\left(x_{1}+x_{3}\right)
$$

and

$$
E V=\frac{\left(p_{1}-p_{2}\right)}{2}\left(x_{2}+x_{4}\right)
$$

Since $x 1<x 3<x 4<x 2$, we have the standard result that $L<C V<\Delta M<E V<P$, where $P$ is the Paasche measure. Since our measure of welfare change is close to a Laspeyres measure we are likely to have underestimated welfare changes.

We discuss these results and assumptions in the context of two alternative measures where $x_{1} \neq x_{2}$. The first is the Marshallian surplus.

If own (arc) elasticity of demand is equal to $\eta$, and cross elasticities are equal to zero, we can write equation (2)

$$
x_{2}-x_{1}=\frac{\eta x_{1}}{p_{1}}\left(p_{2}-p_{1}\right)
$$

so

$$
\Delta M=\left[1+\frac{\eta x_{1}\left(p_{2}-p_{1}\right)}{2 p_{1}}\right] \Delta W
$$

Note that for a price fall, $p_{2}<p_{1}, \eta<0$, so the second term in brackets is positive, confirming that $\Delta \mathrm{M}>\Delta \mathrm{W}$.

We also explore the relationship between $\Delta \mathrm{W}$ and expenditure change, denoted $\Delta \mathrm{E}$, where

$\Delta E=p_{2} x_{2}-p_{1} x_{1}$

Such a measure is relevant to the increasing debate on fuel poverty, which focuses on each household's expenditure on energy. Although the definition is usually related to the need for energy expenditure (as for example in the UK, DTI 2001), the difficulty of identifying each household's need inevitably ends in concentrating on the household's total energy expenditure. The economic interpretation of such a measure is unclear, but it is related to Hope and Singh's (1995) net revenue effect, which includes the cost of delivering energy services.

Using the same assumptions as for deriving (4) we find that 


$$
\Delta E=\left[1+\frac{\eta p_{2}}{p_{1}}\right] \Delta W
$$

For a price fall the second term in brackets is negative, indicating that $\Delta \mathrm{E}<\Delta \mathrm{W}$. Indeed if elasticity were numerically greater than 1 (which we do not believe is the case for electricity), $\Delta \mathrm{E}$ would be negative for a price fall. We use these definitions in discussing the sensitivity of our results to different levels of elasticity.

To apply our methodology, we found the expenditure of each household after the change represented by each scenario, and compared this with expenditure in 2003. The expenditure figure is divided by the (linear) tariff to obtain the annual electricity consumption of each household in 2003, and we assumed that this would not change with change of tariff. To observe the absolute and percentage effect (gains/losses) of each tariff change, we separated households into categories based on education level, size, housing, social protection, and geographical location. We also calculated the standard deviations to see the variation of gains/losses within each household group.

We normalised income for household composition using the OECD Equivalent Scale, and presented it in deciles, based upon the full sample of 25764 . This latter procedure is important in this context because the households for whom electricity consumption cannot be identified are disproportionately from lower income groups. We explored the possibility of compensating for adverse effects of tariff changes through institutional and social support, by creating binary groups based on whether at least one member of the household was holding a Green Card, registered with one of the Social Security Institutions, or receiving an old age pension from the State. We investigated the effect of possible tariff changes based on households living in different provinces, both for tariff changes that were regionally based, and for our other scenarios. We also arranged households under 11 categories based on household head education level, and 15 categories according to the size and structure of household. Finally, to establish the possible link between electricity expenditure and housing, we grouped households based on ownership and type of dwelling.

The next section presents our findings.

\section{Results}

The effects of the different scenarios on different income groups, according to social security status and by province, is shown in tables 6 to 8 in expenditure, and in tables $6 \mathrm{a}$ to $8 \mathrm{a}$ in terms of percentage of household disposable income. For ease of presentation, we deal with averages within each household category, but the variation of gains and losses around these averages is also shown. A positive sign indicates higher welfare, i.e. a fall in household expenditure, while a negative figure indicates lower welfare and higher expenditure. 
Table 6 Average Gains and Losses due to Tariff Changes in different income deciles: Gains (+); Losses (-) (1000000TL) p.a. (standard deviations in brackets)

\begin{tabular}{|c|c|c|c|c|c|c|c|c|c|c|c|c|}
\hline & \multicolumn{12}{|c|}{ Scenarios } \\
\hline & 1 & (SD1) & 2 & (SD2) & 3 & (SD3) & 4 & (SD4) & 5 & (SD5) & 6 & (SD6) \\
\hline$A L L$ & 0 & & 0 & & +3.60 & & -57.98 & & +63.47 & & 0 & \\
\hline \multicolumn{13}{|c|}{ Income Decile } \\
\hline Poorest & -92.49 & (7.96) & -5.49 & $(0.47)$ & +3.66 & $(0.63)$ & -41.21 & (1.44) & +45.79 & (1.52) & -15.57 & (1.34) \\
\hline 2nd & -25.08 & (2.37) & -3.80 & $(0.36)$ & +3.04 & $(0.63)$ & -44.83 & (1.24) & +49.39 & (1.33) & -11.40 & $(1.08)$ \\
\hline 3rd & -11.68 & (1.19) & -1.95 & $(0.20)$ & +3.89 & $(0.77)$ & -48.02 & (1.02) & +53.21 & $(1.05)$ & -7.79 & $(0.80)$ \\
\hline 4th & -8.25 & $(0.85)$ & -1.27 & $(0.13)$ & +3.81 & $(0.77)$ & -50.79 & $(0.74)$ & +55.87 & $(0.79)$ & -5.71 & $(0.59)$ \\
\hline 5 th & +6.33 & $(0.66)$ & -0.63 & $(0.07)$ & +3.16 & $(0.70)$ & -52.53 & $(0.56)$ & +57.59 & $(0.61)$ & -3.80 & $(0.39)$ \\
\hline $6 t h$ & +8.67 & $(0.94)$ & -0.58 & $(0.06)$ & +3.47 & $(0.77)$ & -54.91 & $(0.33)$ & +60.12 & $(0.36)$ & -2.31 & $(0.25)$ \\
\hline $7 t h$ & +9.79 & (1.09) & +0.54 & $(0.06)$ & +3.26 & $(0.77)$ & -57.13 & $(0.10)$ & +62.02 & $(0.16)$ & -0.54 & $(0.06)$ \\
\hline $8 t h$ & +13.74 & (1.53) & +1.10 & $(0.12)$ & +3.85 & $(0.83)$ & -60.99 & $(0.33)$ & +66.48 & $(0.33)$ & +2.75 & $(0.31)$ \\
\hline 9th & +23.89 & (2.70) & +2.65 & $(0.30)$ & +3.72 & $(0.83)$ & -66.88 & (1.01) & +73.25 & $(1.10)$ & +7.96 & $(0.90)$ \\
\hline Richest & +24.89 & (2.90) & +4.98 & $(0.58)$ & +4.98 & $(1.00)$ & -84.62 & (3.11) & +93.08 & $(3.46)$ & +19.91 & (2.32) \\
\hline
\end{tabular}

Table 6a Gains and Losses due to Tariff Changes: Gains (+); Losses (-); \% of household disposable income

\begin{tabular}{|c|c|c|c|c|c|c|c|}
\hline & \multicolumn{6}{|c|}{ Scenarios } & \multirow[t]{2}{*}{ Household Numbers } \\
\hline & 1 & 2 & 3 & 4 & 5 & 6 & \\
\hline$A L L$ & 0.00 & 0.00 & +0.09 & -1.39 & +1.52 & 0.00 & 16385 \\
\hline \multicolumn{8}{|l|}{ Income Decile } \\
\hline 2nd & -1.98 & -0.30 & +0.24 & -3.53 & +3.89 & -0.90 & 1316 \\
\hline 3rd & -0.70 & -0.12 & +0.23 & -2.89 & +3.20 & -0.47 & 1541 \\
\hline $6 t h$ & +0.30 & -0.02 & +0.12 & -1.88 & +2.06 & -0.08 & 1730 \\
\hline $7 t h$ & +0.28 & +0.02 & +0.09 & -1.64 & +1.78 & -0.02 & 1838 \\
\hline 8th & +0.32 & +0.03 & +0.09 & -1.41 & +1.54 & +0.06 & 1820 \\
\hline 9th & +0.42 & +0.05 & +0.06 & -1.17 & +1.28 & +0.14 & 1884 \\
\hline Richest & +0.19 & +0.04 & +0.04 & -0.65 & +0.72 & +0.15 & 2009 \\
\hline
\end{tabular}


Table 7: Average Gains and Losses due to Tariff Changes According to Social Security Institution, Green Card, and State Old Age Pension Categories: Gains (+), Losses (-), (1000000TL) p.a. (standard deviations in brackets)

\begin{tabular}{|c|c|c|c|c|c|c|c|c|c|c|c|c|}
\hline & \multicolumn{12}{|c|}{ Scenarios } \\
\hline & 1 & (SD1) & 2 & (SD2) & 3 & (SD3) & 4 & (SD4) & 5 & (SD5) & 6 & (SD6) \\
\hline$A L L$ & 0 & & 0 & & +3.6 & & -57.98 & & +63.47 & & 0 & \\
\hline \multicolumn{13}{|c|}{ Social Security Institutions } \\
\hline Registered & +7 & $(5)$ & +0.99 & $(0.78)$ & +3.63 & $(5.68)$ & -58.29 & $(0.25)$ & +64.22 & $(0.59)$ & +0.99 & $(0.97)$ \\
\hline Not Registered & -11 & (7) & -1.60 & (0.99) & +3.58 & $(4.44)$ & -55.87 & $(1.30)$ & +62.26 & $(0.75)$ & -1.60 & $(0.84)$ \\
\hline \multicolumn{13}{|l|}{ Green Card } \\
\hline Has & -92 & $(16)$ & -7.80 & $(1.38)$ & +4.13 & $(1.37)$ & -50.68 & $(1.29)$ & +56.53 & (1.23) & -11.70 & (2.03) \\
\hline Has not & +3 & (3) & +0.63 & (0.62) & +3.59 & (7.08) & -57.96 & $(0.02)$ & +63.63 & $(0.16)$ & +0.63 & $(0.86)$ \\
\hline \multicolumn{13}{|c|}{ State Old Age Pension } \\
\hline Receiving & +18 & (4) & -1.38 & (0.29) & +3.50 & $(1.50)$ & -60.61 & $(0.55)$ & +64.74 & $(0.27)$ & -1.38 & $(0.24)$ \\
\hline Not Receiving & -1 & (1) & 0.00 & $(0.00)$ & +3.61 & $(7.05)$ & -58.11 & $(0.13)$ & +63.22 & $(0.245)$ & 0.00 & $(0.24)$ \\
\hline
\end{tabular}

Table 7a: Gains and Losses due to Tariff Changes According to Social Security Institution, Green Card, and State Old Age Pension Categories: Gains (+), Losses (-), \% of household disposable income

\begin{tabular}{|c|c|c|c|c|c|c|c|}
\hline & \multicolumn{6}{|c|}{ Scenarios } & \multirow[b]{2}{*}{ Household Numbers } \\
\hline & 1 & 2 & 3 & 4 & 5 & 6 & \\
\hline$A L L$ & 0.00 & 0.00 & +0.09 & -1.39 & +1.52 & 0.00 & 16385 \\
\hline \multicolumn{8}{|c|}{ Social Security Institutions } \\
\hline Registered & +0.15 & 0.00 & +0.08 & -1.37 & +1.49 & 0.00 & 10121 \\
\hline Not Registered & -0.33 & -0.05 & +0.11 & -2.20 & +2.35 & -0.05 & 6264 \\
\hline \multicolumn{8}{|l|}{ Green Card } \\
\hline Has & -5.78 & -0.49 & +0.26 & -3.20 & +3.57 & -0.74 & 513 \\
\hline Has not & +0.07 & +0.01 & +0.08 & -1.36 & +1.49 & +0.01 & 15872 \\
\hline \multicolumn{8}{|c|}{ State Old Age Pension } \\
\hline Receiving & +0.65 & -0.05 & +0.13 & -2.20 & +2.35 & -0.05 & 726 \\
\hline Not Receiving & -0.02 & 0.00 & +0.09 & -1.37 & +1.49 & 0.00 & 15659 \\
\hline
\end{tabular}


Table 8: Average Gains and Losses due to Tariff Changes According to Province: Gains (+), Losses (-), (1000000TL) p.a. (standard deviations in brackets)

\begin{tabular}{|c|c|c|c|c|c|c|c|c|c|c|c|c|}
\hline & \multicolumn{12}{|c|}{ Scenarios } \\
\hline Provinces & 1 & (SD1) & 2 & (SD2) & 3 & (SD3) & 4 & (SD4) & 5 & (SD5) & 6 & (SD6) \\
\hline$A L L$ & 0,00 & & 0.00 & & +3.60 & & -57.98 & & +63.47 & & 0.00 & \\
\hline İzmir & +58.90 & (3.90) & +6.62 & $(0.44)$ & 0.00 & $(0.24)$ & -54.93 & $(0.20)$ & +60.23 & $(0.22)$ & +3.97 & $(0.28)$ \\
\hline Balıkesir & +61.45 & (2.43) & +7.45 & $(0.29)$ & 0.00 & $(0.14)$ & -67.04 & $(0.36)$ & +70.76 & $(0.29)$ & +11.17 & $(0.45)$ \\
\hline Bursa & +50.93 & (2.77) & +6.86 & $(0.37)$ & +5.29 & $(0.48)$ & -51.91 & $(0.33)$ & +57.79 & $(0.31)$ & +2.94 & $(0.17)$ \\
\hline Kastamonu (P) & +26.77 & (1.04) & -15.30 & $(0.60)$ & +1.17 & $(0.19)$ & -47.80 & $(0.40)$ & +51.63 & $(0.46)$ & -19.12 & $(0.74)$ \\
\hline Zonguldak (P) & +38.46 & (1.64) & -19.23 & $(0.82)$ & +1.07 & $(0.20)$ & -67.31 & $(0.40)$ & +72.12 & $(0.37)$ & -12.82 & $(0.54)$ \\
\hline Kırıkkale (P) & +30.81 & (1.08) & -16.59 & $(0.58)$ & +7.11 & $(0.38)$ & -56.87 & $(0.04)$ & +59.24 & $(0.15)$ & -16.59 & $(0.57)$ \\
\hline Manisa & +41.67 & (2.03) & +6.13 & $(0.30)$ & +0.78 & $(0.21)$ & -49.02 & $(0.44)$ & +52.70 & $(0.52)$ & -1.23 & $(0.05)$ \\
\hline Tekirdağ & +59.88 & (2.28) & +7.98 & $(0.30)$ & 0.00 & $(0.14)$ & -81.84 & $(0.91)$ & +85.83 & $(0.85)$ & +21.96 & $(0.85)$ \\
\hline Kocaeli & +55.87 & (1.80) & +8.38 & $(0.27)$ & 0.00 & $(0.12)$ & -78.21 & $(0.65)$ & +86.59 & $(0.75)$ & +22.35 & $(0.73)$ \\
\hline Antalya & +45.95 & (2.13) & +8.11 & $(0.38)$ & +3.58 & (0.33) & -63.51 & $(0.26)$ & +68.92 & $(0.25)$ & +10.81 & $(0.51)$ \\
\hline Trabzon (P) & +16.33 & $(0.87)$ & -14.29 & $(0.76)$ & +4.98 & $(0.46)$ & -50.00 & $(0.43)$ & +54.08 & $(0.50)$ & -18.37 & $(0.97)$ \\
\hline Aydın & +45.15 & (1.88) & +8.36 & $(0.35)$ & +5.77 & $(0.39)$ & -65.22 & $(0.30)$ & +70.23 & $(0.28)$ & +11.71 & $(0.50)$ \\
\hline Malatya (P) & +14.26 & $(0.54)$ & -14.26 & $(0.54)$ & +8.90 & $(0.47)$ & -46.84 & $(0.42)$ & +50.92 & $(0.47)$ & -20.37 & $(0.76)$ \\
\hline Ankara & +57.65 & (3.04) & +10.48 & $(0.55)$ & +12.05 & $(0.82)$ & -85.95 & $(1.47)$ & +94.34 & (1.63) & +26.21 & (1.39) \\
\hline Samsun (P) & +7.42 & (0.33) & -14.84 & $(0.66)$ & +8.03 & $(0.51)$ & -47.48 & $(0.46)$ & +51.93 & $(0.51)$ & -19.29 & $(0.84)$ \\
\hline İstanbul & +23.46 & (2.06) & +7.19 & $(0.63)$ & 0.00 & (0.32) & -60.16 & $(0.19)$ & +64.70 & $(0.11)$ & +7.19 & $(0.65)$ \\
\hline Adana & +3.51 & (0.23) & +5.62 & $(0.36)$ & +6.57 & $(0.65)$ & -48.49 & $(0.61)$ & +52.00 & $(0.74)$ & -1.41 & $(0.07)$ \\
\hline Erzurum (P) & -51.42 & (1.47) & -15.25 & $(0.44)$ & +3.44 & $(0.20)$ & -51.42 & $(0.19)$ & +57.45 & $(0.17)$ & -17.38 & $(0.49)$ \\
\hline Ağrı (P) & -92.86 & (2.44) & -12.18 & $(0.32)$ & +5.71 & $(0.25)$ & -41.60 & $(0.43)$ & +46.22 & $(0.45)$ & -21.01 & $(0.55)$ \\
\hline Şanlıurfa (P) & -359.92 & (13.57) & -16.36 & $(0.62)$ & 0.00 & $(0.14)$ & -57.26 & $(0.03)$ & +63.39 & $(0.00)$ & -14.31 & $(0.53)$ \\
\hline $\operatorname{Van}(P)$ & -532.29 & $(15.40)$ & -14.93 & $(0.43)$ & +4.62 & $(0.24)$ & -53.13 & $(0.14)$ & +58.68 & $(0.14)$ & -18.40 & $(0.53)$ \\
\hline Mardin (P) & -592.65 & $(16.66)$ & -15.44 & $(0.43)$ & +12.79 & $(0.46)$ & -55.88 & $(0.06)$ & +62.13 & $(0.04)$ & -15.44 & $(0.43)$ \\
\hline
\end{tabular}

$\mathrm{P}=$ Province with Priority Status 
Table 8a: Gains and Losses due to Tariff Changes According to Province:

Gains (+), Losses (-) \% of household disposable income

\begin{tabular}{|c|c|c|c|c|c|c|c|}
\hline \multirow[b]{2}{*}{ Provinces } & \multicolumn{6}{|c|}{ Scenarios } & \multirow[b]{2}{*}{$\begin{array}{c}\text { Household } \\
\text { Numbers }\end{array}$} \\
\hline & 1 & 2 & 3 & 4 & 5 & 6 & \\
\hline$A L L$ & 0.00 & 0.00 & +0.09 & -1.39 & +1.52 & 0.00 & 16385 \\
\hline İzmir & $+1,17$ & +0.12 & 0.00 & -1.03 & 1.13 & +0.08 & 1511 \\
\hline Balıkesir & $+1,61$ & +0.12 & 0.00 & -1.11 & 1.17 & +0.29 & 537 \\
\hline Bursa & $+1,33$ & +0.14 & +0.14 & -1.04 & 1.16 & +0.08 & 1021 \\
\hline Kastamonu (P) & $+0,80$ & -0.36 & +0.03 & -1.13 & 1.22 & -0.57 & 523 \\
\hline Zonguldak (P) & $+1,17$ & -0.39 & +0.03 & -1.36 & 1.46 & -0.39 & 624 \\
\hline Kırıkkale (P) & $+1,02$ & -0.40 & +0.23 & -1.36 & 1.41 & -0.55 & 422 \\
\hline Manisa & $+1,39$ & +0.14 & +0.03 & -1.11 & 1.19 & -0.04 & 816 \\
\hline Tekirdağ & $+1,44$ & +0.12 & 0.00 & -1.22 & 1.28 & +0.53 & 501 \\
\hline Kocaeli & $+1,30$ & +0.13 & 0.00 & -1.17 & 1.30 & +0.52 & 358 \\
\hline Antalya & $+0,92$ & +0.13 & +0.07 & -1.05 & 1.14 & +0.22 & 740 \\
\hline Trabzon (P) & $+0,45$ & -0.34 & +0.14 & -1.20 & 1.30 & -0.50 & 980 \\
\hline Aydın & $+1,09$ & +0.13 & +0.14 & -0.98 & 1.05 & +0.28 & 598 \\
\hline Malatya (P) & $+0,42$ & -0.37 & +0.26 & -1.22 & 1.32 & -0.60 & 491 \\
\hline Ankara & $+1,03$ & +0.12 & +0.22 & -1.02 & 1.12 & +0.47 & 954 \\
\hline Samsun (P) & $+0,28$ & -0.48 & +0.31 & -1.52 & 1.67 & -0.74 & 674 \\
\hline İstanbul & $+0,38$ & +0.11 & 0.00 & -0.92 & 0.99 & +0.12 & 2643 \\
\hline Adana & $+0,11$ & +0.14 & +0.20 & -1.24 & 1.33 & -0.04 & 1423 \\
\hline Erzurum (P) & $-1,89$ & -0.49 & +0.13 & -1.65 & 1.84 & -0.64 & 282 \\
\hline Ağrı (P) & $-3,14$ & +0.38 & -0.19 & +1.28 & 1.43 & -0.71 & 238 \\
\hline Şanlıurfa (P) & $-14,92$ & +0.34 & 0.00 & +1.19 & 1.32 & -0.59 & 489 \\
\hline $\operatorname{Van}(P)$ & $-18,90$ & +0.37 & -0.16 & +1.31 & 1.44 & -0.65 & 288 \\
\hline Mardin (P) & $-24,88$ & +0.39 & -0.54 & +1.41 & 1.56 & -0.65 & 272 \\
\hline
\end{tabular}

$\mathrm{P}=$ Province with Priority Status 


\subsection{Changes in regional tariffs (scenarios 1,2 and 3)}

Scenario 1 demonstrates the effect of charging provinces for the technical and nontechnical losses which they incur, while leaving the overall amount of revenue collected the same as in 2003. This is the sort of change proposed by EMRA, but postponed for at least five years, and replaced by a tariff equalisation scheme (scenario 2), which would at least charge priority provinces, which tend to have large losses, the same as households in the rest of Turkey. Reflecting the losses fully in prices implies very large increases for some provinces (as shown in table 8), and for some household groups. In tables 6 and $6 a$ we see the effect on income deciles of raising prices predominantly in lower income provinces. In the case of Mardin, which faces the highest increase and is almost the poorest province, prices which reflected all the lost electricity would need to rise by $170 \%$. Table 8 a shows that the increase represents a quarter of average income. Losses are correspondingly much greater in both absolute and relative terms for the poorest decile, amounting to an increased expenditure which accounts for an average of an eighth of the income of this group. The standard deviation is comparatively low, indicating that there is little variation around this average and that there is a significant difference in the mean expenditure of each income group. Such a change is not surprising from a static analysis of raising prices by such a large amount, and it is perhaps understandable that the government shied away from implementing such a scheme in the short run. However for this scenario in particular, our static assumption of no demand response is unrealistic, since such a large increase would be likely to stimulate both institutional and individual responses. Applying an own price elasticity of -0.25 adds another fifth to the loss of (Marshallian) surplus for the worst affected provinces, though for the most efficient provinces the proportionate gain is much smaller because the price falls are much lower than the potential price increases. Thus while our scenario identifies the amount of revenue to be raised, it is probable that some of the nontechnical losses would be rapidly reduced, thus collecting the revenue from a larger base of electricity users, and reducing the average price necessary. Nevertheless the scenario is informative in terms of relative changes and the huge regional impact of the losses currently experienced.

If the losses were indeed to be recovered from consumers who currently have no electricity expenditure but are using power, they would of course be worse off by the amount that they now had to pay for energy. We have shown that the 7010 consumers who did not report any electricity expenditure are predominantly low income, and from the provinces with high losses. While we cannot identify the exact impact, because we do not know about their actual (as opposed to recorded) consumption, the effect of recouping these loses would be regressive. For example we see from table 1 that if those with missing values consume electricity in amounts similar to the consumption of households in the same income decile whose consumption is recorded, half of those in decile 1 would face a bill of $351000000 \mathrm{TL}$ per year, while the corresponding figures for the richest decile are that $17 \%$ would face a bill of 503000000TL.

The regressive effects of reflecting losses in tariffs might be mitigated through use of the Green Card, since the average losses for holders of such cards are similar to those for the poorest decile, compared with a small gain for the much greater number who do not have such cards (table 7). The standard deviation of gains for this group 
is much higher than for other groups we have analysed, perhaps reinforcing doubts about whether Green Cards are necessarily held by those in greatest need (Gürsel, 2004: 157). However those registered with social security institutions actually gain from the changes, as do those receiving old age pensions, suggesting that these institutions could not be easily used to help smooth any unwanted adverse effects.

Scenario 2, the effect of removing the small discount for priority status provinces, again in a revenue-neutral way, has an effect in a similar direction, but much smaller in size, than scenario 1, with, by design, no effect on average expenditure. The poorest deciles lose and the richest gain on average, reflecting the higher concentration of lower income groups in the priority provinces, as we might expect and suggesting that the current priority status is well targeted for income equalisation effects. The absolute average gain for the richest decile is not statistically significantly greater than the loss for the poorest decile, but the poor lose considerably more as a proportion of their income than the rich gain relative to theirs. Those who have a Green Card, receive an old age pension, or are not protected by a social security umbrella, suffer losses from the removal of priority status. In regional terms, the effect of scenario 2 is, like scenario 1, directly geographical, so the main interest is the size rather than the direction of the gains/losses. Amongst non-priority provinces, Ankara households gain most on average, while amongst the priority provinces, Zonguldak households would lose most.

Unlike scenarios 1 and 2, scenario 3 is not revenue-neutral, but proposes lower tariffs (and therefore net gains) in provinces which have the potential to improve their efficiency levels. In this way it is directly opposite in spirit and direction to scenarios 1 and 2, where tariffs are raised (by very different amounts) in the provinces where there are currently high losses. This is shown in Table 7, where the provinces which would have greatest price rises under scenarios 1 and 2, would have the greatest price reductions with scenario 3 . We see that differences between average gains are not statistically significant across deciles, despite a tendency for higher average absolute gains for the richest tenth of households. The proportionate gain is correspondingly greatest, about half of one percent, for the poorest decile, compared with a tenth of this proportion for the richest. The effect of this hypothetical illustrative change is very small because of the relatively small share of distribution in retail price (around $10 \%$ ). The change is relative to the current tariff structure, i.e. with priority province status maintained, so to some extent scenarios 2 and 3 would counteract each other, being of similar magnitude, and opposite direction. There is little difference in the effects according to social security membership or receipts.

\subsection{Changing the level of revenue collected from residential consumers (scenarios 4 and 5)}

Since the price rise of scenario 4 (raising the proportion of electricity revenue recovered through the residential tariff to the OECD average) and the fall in scenario 5 (removing all taxes and reimposing 5\% VAT) are similar in magnitude, the effects are broadly equal and opposite. Each of these two changes in the level of household tariffs increases (or decreases) expenditure by around $1.5 \%$ of disposable income on average. Absolute gains (losses) increase with income, but percentage gains (losses) fall as income rises, following the pattern of electricity expenditure. We see that the poorest decile loses (gains) between five to six percent of household income 
on average, a very substantial proportion. Conversely, while the rich stand to lose (gain) more in absolute amounts, this represents a much smaller proportion of their income, less than $0.8 \%$ for the richest decile. This absolute/proportionate effect arises directly from the characteristic of energy consumption that demand increases with income, but at a decreasing rate, as demonstrated in section 2 above. This pattern is mirrored for educational achievement (tables A4 and A4a), with absolute gains (losses) increasing with educational level, but gains as a proportion of income decreasing. This follows directly from the positive relationship between income and educational level.

Table 7 shows that those with a Green Card lose (gain) less than the mean in absolute terms, but more in proportionate terms, on average between 3 and $4 \%$ of disposable income. This suggests that any hardship could be partially addressed through the Green Card mechanism. There is little difference in the absolute amounts gained (lost) according to Social Security registration, but for those not registered the changes represent a higher proportion of income. The elderly lose (gain) a little more than average, and the change represents a higher proportion of their income. Regional differences for these scenarios are related directly to the average levels of household consumption in each province (table 8 ) and the different income levels. Though the tariff changes are uniform throughout the country, the effects are not. Households in Samsun, Erzurum and Mardin would lose (or gain) a higher proportion of their income than elsewhere, with the greatest absolute gains (losses) in Ankara.

The largest absolute effects of scenarios 4 and 5 are on larger families (table A5 and A5a), and the largest proportionate effects on parents with three children and larger families with children. (Recall that income is normalised for family structure). So we might be most concerned about the effects on large families, both with young and older children. This arises because they have higher electricity expenditure, and relatively low (normalised) household income. Those who have housing provided by their employer lose (gain) more than average under scenario 4 (5), while everyone else, except those dwelling in their own house, gains (loses) less than average (tables A6 and A6a). Those in shanty houses and in detached houses seem to lose (gain) less than those living in semi-detached houses and apartments but more than other households; but there is no great variation in the average proportions for each group. The only groups who lose or gain more than an average proportion are those who live in shanty houses, reflecting their lower than average absolute expenditure and slightly above average proportionate expenditure (table A3).

\subsection{Restructuring tariffs (Scenario 6)}

The revenue-neutral introduction of a standing charge (scenario 6) benefits those who consume more electricity and penalises users of small quantities. This results in absolute losses for the poorest deciles and higher absolute gains for the richest. But as a proportion of income, the poorest decile loses on average over $2 \%$ of disposable income, while the richest gains less than $0.2 \%$ (tables 6 and $6 \mathrm{a}$ ). This relation is mirrored by the gain acquired by those with higher education whose electricity consumption and income is relatively high (tables A4 and A4a). People who are more vulnerable and likely to consume less electricity, i.e. those with a Green Card, not registered with social security, or receiving an old age pension, face increased 
expenditure (tables 7 and 7a). As a proportion of income, the losses are greatest for Green Card holders.

Households in provinces with priority status lose on average because their electricity expenditure is low. Average absolute losses are greatest in Agri and average losses as a proportion of income in Samsun (tables 8 and 8a). Two non-priority provinces, Manisa and Adana, experience small average losses. Amongst other non-priority provinces, Ankara, Kocaeli, and Tekirdag enjoy the highest absolute reduction in electricity expenditure, reflecting their higher average household electricity consumption. The biggest average gain as a proportion of income accrues in Kocaeli.

The introduction of the standing charge appears to have the worst absolute effect on single adult households, who would be expected to have low levels of consumption, while (rather surprisingly) parents with more than three children lose on average $0.3 \%$ of their (normalised) disposable income (tables A5 and A5a). Shanty house dwellers and those who own their own homes lose from the introduction of a standing charge, with the greatest loss relative to income experienced by home owners (tables $\mathrm{A} 6$ and $\mathrm{A} 6 \mathrm{a})$.

\section{Effect of demand response}

In our main analysis, we have followed other studies in assuming zero demand response to changes in tariffs. While this seems reasonable for small price changes, some of those we are examining would result in enormous changes in tariff levels for regions or individuals, and are likely to elicit some institutional or household level response. We discuss the likely effects of these on the 'first order' results which we have reported above.

Where our scenarios involve the same price changes for all households (or all households in a particular region), we can estimate quantitatively the average effects on each group. We have discussed this above for the large tariff increases to reflect regional losses, and see that if these were imposed with no increase in the consumer base from which to collect revenues, the loss in consumer surplus is $20 \%$ greater than the reference welfare measure we have used. In most cases, the effect of including elasticities in measuring welfare changes is much smaller, increasing the measure by only about $2 \%$. We also explored the effect of differential elasticities according to income level, with higher responses amongst low income households, basing our elasticities for each decile loosely on Reiss and White (2002), with the constraint that they average to -0.25 to be consistent with our overall elasticity assumptions. We estimated aggregate responses for those price changes where the ratio of the new to old price was the same for all consumers in any one income decile (scenarios 4 and 5). With elasticities of -0.6 for the poorest group (and -0.05 for the richest), the additional loss (gain) from a price rise (fall) was around $5 \%$ for the lowest income decile and $0.4 \%$ for the richest.

\section{Expenditure and Fuel Poverty}

We have considered welfare measures rather than expenditure changes, but with increasing emphasis on fuel expenditure as a proportion of income, particularly in the 
context of affordability (e.g. EBRD 2003), we can extend our analysis to examine the likely effect on total expenditure, particularly of the very large changes we have proposed for different provinces. With no price responsiveness, the change in expenditure is the same as our welfare measure. But where there is a demand response, change in expenditure will be correspondingly lower than the basic welfare measure. For example, assuming elasticity of (minus) $25 \%$, the change in expenditure in Mardin would be $67 \%$ less than our basic welfare measure (which in itself we have seen $20 \%$ less than a Marshallian measure for such a level of demand response). The welfare measure is higher because it includes the benefits from the energy which the household no longer uses. From a policy perspective, the appropriate concern about this depends on whether the household cannot function adequately as a result of the economies, either in terms of lighting, power and air conditioning or, more rarely in Turkey, heating.

\section{Summary and conclusions}

The illustrative scenarios used in this paper have been chosen to identify the effects on households of different changes that may arise from reforming the Turkish electricity industry. The most dramatic change in tariffs is likely to come from a restructuring to make them more cost reflective, should this be allowed, and we have looked at two possibilities: reflecting regional losses, which would, on the face of it, incur huge increases in tariffs in some (low income) regions; and introducing a ten per cent standing charge to reflect the fixed costs of retail tariffs. Overall, we have deliberately chosen a variety of scenarios, with very different effects, so that the magnitude of different changes can be seen.

The large change in regional tariffs from reflecting regional losses in prices is likely to trigger other changes, including the recovery of more non-technical losses, which would itself moderate the increases which we identify in some provinces. Nevertheless such changes are likely to have a large adverse effect on households in such provinces, through a mixture of enforcing payment on some who currently receive electricity free, and raising the prices to all bill payers. Such changes are likely to be politically sensitive, and to need considerable delicacy. But our analysis shows the extent to which non-payment of such bills is currently subsidising such provinces from consumers who live elsewhere. It is unlikely that either they or private investors will continue to tolerate such subsidies once they become transparent, so some move to recover more electricity revenue from high loss provinces seems an inevitable part of the reform process. Removing the current small subsidy for priority provinces (scenario 2) would at least be a move in the right direction, but underlines that the changes to reflect costs would hit poorer (and more politically sensitive) regions hardest. The current priority status does lower the average price for low income families more than others, though low income households in the non-priority provinces are adversely affected. The price differential is minute, and the consequences of removing it correspondingly small, even allowing for some demand responsiveness. It may well be that other factors in the priority provinces (for example a lower proportion of industrial demand, which is generally less peaky and so less expensive, and less well developed infrastructure) raise costs in these areas relative to the rest of the country. If this were the case, and tariffs became cost reflective, the small tariff rises which we identify from abolishing the preferential 
status of priority provinces might be considerably larger. Green Card holders and old age pensioners could be compensated, but this will be a very blunt instrument, compensating many who have not been adversely affected or have benefited from regional rebalancing (e.g. in non-priority provinces) and missing many households not in these categories who see increased bills as a result of the change. A credible scheme to move towards cost recovery at a pace which is tolerable for all parties needs urgently to be devised.

The other major cost reflective move, the institution of a $10 \%$ standing charge, to reflect the portion of retail costs which are independent of the amount which each consumer uses, would also be regressive. Our scenario assumed revenue-neutrality, i.e. the total amount of revenue raised from the retail sector after the change is the same as before. The introduction of such a fixed charge is detrimental for consumers who use small quantities of electricity and beneficial for those with large consumption. This means that gains are greatest for those with high incomes and the losses greatest for those with low incomes, both absolutely and, even more, as a proportion of income. The lowest income group would lose at least $2 \%$ (on average) of their household income from this comparatively modest change, given our conservative assumptions. If a (still conservative) elasticity of demand of -0.6 were included for this group, the loss in welfare would be higher, and would be considerably greater for low income households with low energy demand. Pressure for such cost reflectivity in tariff structure is also likely to come from reform, and adverse effects on low income households will need to be addressed both to ensure political acceptability and to alleviate hardship.

A more encouraging aspect of reform is cost reductions. We have considered the effect of one particular potential cost saving which we have identified from other work, namely the extension of best practice in distribution to all the distribution companies. In our scenario we have assumed that price levels would fall accordingly (taking account of the small proportion which distribution represents in the final retail bill), and analysed the effects on the regions affected. But we note a policy of uniform geographic pricing. In this case the small reductions which we analyse would be spread across the whole country, meaning smaller changes for all regions, including those which are already demonstrating best practice in this area. But the main point to note is that in reality cost savings are likely to be much greater than these particular changes suggest. Although the industry has already reduced employment by $30 \%$, anecdotal evidence suggests that further efficiency gains are available from improved working practices. Privatisation will provide incentives for such changes, albeit dampened by the cost of service regulation, which may also delay somewhat the reflection of cost savings in tariffs. Nevertheless we would expect some substantial cost (and eventually price) reductions from efficiency improvements.

The fact that the taxes currently levied on the industry largely correspond to the relatively low (compared with other OECD countries) proportion of revenue collected through the residential sector indicates that adjusting for both these factors would be broadly neutral in its effects on overall residential tariff levels. Analysis of each change confirms that uniform price increases have a smaller absolute and greater proportionate (to income) effect on vulnerable households, particularly those with low income or in possession of a Green Card or receipt of old age pensions. Large 
families experience higher than average losses in both absolute terms and relative to their (equivalised) income. This pattern means that it might be possible to compensate Green Card holders and old age pensioners for the adverse effects of increases in the price level through their entitlements, but will leave other low income and vulnerable households outside this safety net. In practice, lower cost levels from reform would have similar effects to scenario 5 , though not necessarily at this level. To the extent that national pricing results in uniform price reductions to all consumers, the effects will be similar to those described in scenario 5, i.e. greatest absolute benefit to high income and well educated households, but greatest benefit as a proportion of income to low income households and those with less formal education.

Overall we can see that changing tariff levels or structures have different effects on different households, with consequences both for the hardship (or benefits) which different groups experience and for the political support which the reforms are likely to generate. Some of the changes have a significant impact, particularly as a proportion of income on low income households. Moreover if several reforms were to be combined, in particular reflection of regional losses and the standing charge, some low income households would be very adversely affected. Where existing safety nets can provide adequate protection they should be used, and where they do not, alternative safety nets, or perhaps a careful sequencing of changes so that they do not occur too suddenly, need to be devised. Any delay requires a delicate balance with the credibility of the programme itself in the teeth of powerful counterforces from interested parties and political opposition. 


\section{References}

Atiyas, I. and M. Dutz (2005), "Competition and Regulatory Reform in Turkey's Electricity Industry", in Bernard M. Hoekman and Subidey Togan (eds.) Turkey: Economic Reform and Accession to the European Union, a co-publication of the World Bank and CEPR, Washington, 187-208.

Bagdadioglu, N., C. Waddams Price and T. Weyman-Jones (2007), "Measuring Potential Gains from Mergers among Electricity Distribution Companies in Turkey using a Non-Parametric Model", Energy Journal 28(2): 83-110.

Baker, P., R. Blundell and J. Micklewright (1989), "Modelling Household Energy Expenditures Using Micro-data", Economic Journal 99: 720-738.

Cetin, T. and F. Oguz (2007), "The Politics of Regulation in the Turkish Electricity Market”, Energy Policy 35(3): 1761-1770.

DTI Energy Group (2001), The UK Fuel Poverty Strategy, available at:

http://www.dti.gov.uk/energy/consumers/fuel_poverty/fuel_strategy.shtml (accessed 02 December 2005).

European bank for Reconstruction and Development, 2003, Can the Poor Pay for Power? The Affordability of Electricity in South East Europe, mimeo, November.

Electricity Sector Reform and Privatisation Strategy Paper (2004) Privatisation Administration, 2004 http://www.oib.gov.tr/program/2004 program/2004 electricity strategy paper.htm (accessed 05/02/2006)

EMRA (2004), Annual Report, Energy Market Regulatory Authority http://www.epdk.org.tr (accessed 16/02/2006)

European Commission (2005), the Energy Community Treaty, http://europa.eu.int/comm/energy/electricity/south east/treaty en.htm (access on 11th May 2006).

Gursel, S. (2004), "Gelir Dağılımı ve Yoksullukla Mücadele Stratejileri”, 2004 Türkiye Iktisat Kongresi, Panel Oturumları, Cilt.15, sf: 110-158, Atatürk Kültür Merkezi, İzmir. ("Income Distribution and Poverty Reduction Strategies" 2004 Turkish Economic Congress, Panel Sessions, Vol.15, pp: 110-158)

Hepbasli, A. (2005), "Development and Restructuring of Turkey's Electricity Sector: A Review", Renewable and Sustainable Energy Reviews 9: 311-343.

Hope, E. and B. Singh (1995), "Energy Price Increases in Developing Countries:

Case Studies of Colombia, Ghana, Indonesia, Malaysia, Turkey, and Zimbabwe", The World Bank Policy Research Working Paper, 1442.

IEA (2004), International Energy Agency Statistics - Electricity Information, International Energy Agency.

IEA (2002), World Energy Outlook, International Energy Agency.

IRG (2005), Tariff Benchmarking, International Research Group. http://ec.europa.eu/energy/electricity/south east/doc/mf 2006/tariff benchmarking usaid report.pdf (accessed on 15th May 2006)

Isik, Y. (2004), "Turkey's Energy Prospects in the EU-Turkey Context", Centre for European Policy Studies, EU-Turkey Working Paper No.9/October. http://www.isn.ethz.ch/pubs/ph/details.cfm?lng=en\&id=20727 (accessed on $28^{\text {th }}$ August 2006).

Monopolies and Mergers Commission (1997), BG plc, May, London: Stationary Office.

Newbery, D. M. and M. Pollitt (1997), "The Restructuring and Privatisation of Britain's CEGB-Was it worth it", Journal of Industrial Economics XLV(3): 269-303. 
OFGEM (2006), Updated - Household Energy Bills Explained, OFGEM factsheet 52, 12.04.2006.

http://www.ofgem.gov.uk/temp/ofgem/cache/cmsattach/14692 energypricesupdate apr6.pdf?wtfrom=/ofgem/press/fact-sheets.jsp (accessed on 07th June 2006)

Ozkivrak, O. (2005), "Electricity Restucturing in Turkey", Energy Policy 33: 13391350.

Reiss, Peter C. and Matthew W. White (2005) "Household Electricity Demand,

Revisited", Review of Economic Studies 72(3): 853-883.

TEDAS (2004), 2003 Annual Report, Turkish Electricity Distribution Company, Ankara.

TSIS (2004), 2003 Turkish Household Expenditure Survey, Turkish State Institution of Statistics, Ankara.

Ugaz C. and C. Waddams Price (2003), Utility Privatization and Regulation, Edward Elgar Publishing, Glos, UK.

Waddams Price C. and R. Hancock (1998), "Distributional Effects of Liberalising UK Residential Utility Markets", Fiscal Studies 19(3):. 295-319.

World Bank (2005), Turkey - Electricity Distribution Rehabilitation Project, http://wwwwds.worldbank.org/external/default/WDSContentServer/IW3P//B/2005/09/13/00010 4615 20050914092018/Rendered/PDF/ProjectOInform1e0updated00801002005.pd f (accessed on 11th May 2006)

World Bank and TSIS (2005), Turkey - Joint Poverty Assessment Report, Document of Human Development Sector Unit Europe and Central Asia Region and Turkish State Institute of Statistics, World Bank. http://www-

wds.worldbank.org/external/default/WDSContentServer/IW3P/IB/2005/10/12/00001 2009 20051012161856/Rendered/PDF/296190rev0v1.pdf (accessed on 11th May 2006) 


\section{Appendix: Energy consumption and its relation to other household characteristics}

Table A1: Household Electricity Expenditure and Education Level

\begin{tabular}{|l|c|c|c|}
\hline \multicolumn{1}{|c|}{ Education level } & $\begin{array}{c}\text { Average electricity } \\
\text { expenditure per } \\
\text { household p.a. } \\
\text { (1000000TL) }\end{array}$ & $\begin{array}{c}\text { Standard deviation of } \\
\text { electricity expenditure } \\
\text { (1000000TL) }\end{array}$ & $\begin{array}{c}\text { Expenditure as } \\
\% \text { of } \\
\text { disposable } \\
\text { income }\end{array}$ \\
\hline \multicolumn{1}{|c|}{ Average } & 359 & & 9 \\
\hline \multicolumn{1}{|c|}{} & & 274 & 12 \\
\hline Illiterate & 279 & 219 & 10 \\
\hline Literate (no formal & 287 & 205 & 11 \\
\hline Primary (5 years) & & & 9 \\
\hline Secondary & 333 & 267 & 8 \\
\hline Secondary (vocational) & 355 & 243 & 8 \\
\hline High & 333 & 276 & 8 \\
\hline High (vocational) & 391 & 231 & 7 \\
\hline University (2 years) & 403 & 253 & 5 \\
\hline University (4 years) & 428 & 346 & 4 \\
\hline Master/PhD & 508 & 435 & \\
\hline
\end{tabular}

${ }^{*}$ Two households with education level primary (8 years) were omitted because of their small number and atypical results.

Table A2: Household Electricity Expenditure and Household Structure

\begin{tabular}{|c|c|c|c|}
\hline Household structure & $\begin{array}{l}\text { Average electricity } \\
\text { expenditure per } \\
\text { household p.a. } \\
(1000000 T L)\end{array}$ & $\begin{array}{l}\text { Standard deviation } \\
\text { of electricity } \\
\text { expenditure } \\
\text { (1000000TL) }\end{array}$ & $\begin{array}{c}\text { Expenditure as } \\
\% \text { of } \\
\text { disposable } \\
\text { income }\end{array}$ \\
\hline Average & 359 & 274 & 9 \\
\hline & & & \\
\hline Single adult* ${ }^{\star}$ & 244 & 166 & 3 \\
\hline Single parent with children (18-) & 290 & 189 & 8 \\
\hline $\begin{array}{l}\text { Single parent with children } \\
\text { (one child } 18+\text { ) }\end{array}$ & 336 & 275 & 8 \\
\hline Childless couple & 318 & 219 & 6 \\
\hline Parents with one child (18-) & 360 & 277 & 7 \\
\hline Parents with one child (18+) & 391 & 317 & 8 \\
\hline Parents with two child (18-) & 351 & 235 & 9 \\
\hline $\begin{array}{l}\text { Parents with two children } \\
\text { (one child } 18+\text { ) }\end{array}$ & 413 & 274 & 10 \\
\hline $\begin{array}{l}\text { Parents with three children or more } \\
(18-)\end{array}$ & 334 & 241 & 14 \\
\hline $\begin{array}{l}\text { Parents with three children or more } \\
\text { (at least one child } 18+\text { ) }\end{array}$ & 397 & 346 & 14 \\
\hline Larger family** & 384 & 241 & 9 \\
\hline Larger family with children (18-) & 390 & 314 & 13 \\
\hline $\begin{array}{l}\text { Larger family with children } \\
\text { (at least one child } 18+\text { ) }\end{array}$ & 415 & 341 & 15 \\
\hline $\begin{array}{l}\text { Individuals living in the same house } \\
\text { (Students, workers etc.) }\end{array}$ & 355 & 232 & 5 \\
\hline Relatives living in the same house & 336 & 261 & 7 \\
\hline
\end{tabular}


Table A3: Household electricity expenditure and dwelling ownership and type

\begin{tabular}{|c|c|c|c|}
\hline & $\begin{array}{l}\text { Average electricity } \\
\text { expenditure per } \\
\text { household p.a. } \\
(1000000 T L)\end{array}$ & $\begin{array}{l}\text { Standard deviation of } \\
\text { electricity expenditure } \\
(1000000 T L)\end{array}$ & $\begin{array}{l}\text { Expenditure as \% } \\
\text { of disposable } \\
\text { income }\end{array}$ \\
\hline Average & 359 & 274 & 9 \\
\hline \multicolumn{4}{|l|}{ Ownership } \\
\hline Household owned & 366 & 290 & 9 \\
\hline Tenant & 340 & 226 & 9 \\
\hline Provided by employer & 405 & 229 & 8 \\
\hline Other & 336 & 257 & 9 \\
\hline \multicolumn{4}{|l|}{ Type } \\
\hline Detached house & 325 & 275 & 11 \\
\hline $\begin{array}{l}\text { Semi-detached and } \\
\text { apartment }\end{array}$ & 378 & 273 & 8 \\
\hline Shanty house & 326 & 258 & 12 \\
\hline Other & 290 & 185 & 8 \\
\hline
\end{tabular}

As expected, electricity expenditure broadly increases with household size (see table A3). Since our income measure is normalised for household size and structure, we would expect income and household size to move broadly together. However we note that electricity expenditure is a particularly low proportion of the (normalised) income of single adults whether living individually or in the same house; and that it is particularly high relative to the income of families with three or more children.

The pattern of expenditure with respect to dwelling (table A4) shows little variation between ownership types, though, perhaps surprisingly, a higher absolute expenditure by those living in employer-provided accommodation. The fact that the proportionate expenditure is no greater suggests that these householders have higher than average income. Those living in all the categorised types of dwelling spend a similar amount on electricity, but this represents a higher proportion of (normalised) income for those in detached and shanty houses. 
Table A4: Average Gains and Losses due to Tariff Changes Depending Upon Household Head Education: Expenditure Gains (+); Losses (-) (1000000TL) p.a. (standard deviations in brackets)

\begin{tabular}{|c|c|c|c|c|c|c|c|c|c|c|c|c|}
\hline \multirow[b]{2}{*}{ Household Head Education } & \multicolumn{11}{|c|}{ Scenarios } & \multirow[b]{2}{*}{ (SD6) } \\
\hline & 1 & (SD1) & 2 & (SD2) & 3 & (SD3) & 4 & (SD4) & 5 & (SD5) & 6 & \\
\hline$A L L$ & 0.00 & & 0.00 & & +3.60 & & -57.98 & & +63.47 & & 0.00 & \\
\hline Illiterate & -60.57 & (4.51) & -4.41 & (0.33) & +3.41 & $(0.52)$ & -45.15 & $(0.95)$ & +48.46 & $(1.12)$ & -12.11 & $(0.88)$ \\
\hline Literate (no formal education) & -22.95 & $(1.63)$ & -2.42 & $(0.17)$ & +2.96 & $(0.47)$ & -45.89 & $(0.86)$ & +50.72 & $(0.91)$ & -9.67 & $(0.67)$ \\
\hline Primary ( 5 year) & +7.50 & $(1.66)$ & 0.00 & $(0.00)$ & +3.20 & $(1.50)$ & -53.74 & $(0.94)$ & +58.74 & $(1.05)$ & -2.50 & $(0.50)$ \\
\hline Secondary & +1.68 & $(0.18)$ & -0.56 & $(0.06)$ & +3.71 & $(0.76)$ & -57.27 & $(0.07)$ & +62.89 & $(0.06)$ & -0.56 & $(0.03)$ \\
\hline Secondary (vocational) & +20.83 & $(0.44)$ & +2.78 & $(0.06)$ & +2.19 & $(0.12)$ & -52.78 & $(0.11)$ & +59.72 & $(0.08)$ & 0.00 & $(0.01)$ \\
\hline High & -11.41 & $(1.37)$ & +0.42 & $(0.05)$ & +4.01 & $(0.92)$ & -61.28 & $(0.40)$ & +68.89 & $(0.65)$ & +3.38 & $(0.44)$ \\
\hline High (vocational) & +20.99 & (1.34) & +1.50 & $(0.10)$ & +3.87 & $(0.48)$ & -64.47 & $(0.41)$ & +71.96 & $(0.54)$ & +6.00 & $(0.40)$ \\
\hline University (two year) & +10.90 & $(0.52)$ & -2.72 & $(0.13)$ & +4.93 & $(0.40)$ & -70.84 & $(0.61)$ & +73.57 & $(0.48)$ & +5.45 & $(0.27)$ \\
\hline University (4 year) & +5.51 & $(0.49)$ & +2.36 & $(0.21)$ & +5.17 & $(0.77)$ & -81.89 & $(2.11)$ & +88.98 & $(2.25)$ & +16.54 & $(1.48)$ \\
\hline Master, PhD & +47.54 & $(1.30)$ & +9.02 & $(0.25)$ & +5.86 & $(0.26)$ & -109.84 & (1.42) & +118.85 & (1.51) & +39.34 & $(1.08)$ \\
\hline
\end{tabular}


Table A4a: Gains and Losses due to Tariff Changes Depending Upon Household Head Education: Gains (+); Losses (-) \% of household disposable income

\begin{tabular}{|l|c|c|c|c|r|r|r|}
\hline \multicolumn{7}{|c|}{ Sousehold Head Education } & \multicolumn{7}{c|}{ Scenarios } & \multicolumn{1}{c|}{} \\
\hline \multicolumn{1}{|c|}{$\boldsymbol{A L L}$} & $\mathbf{1}$ & $\mathbf{2}$ & $\mathbf{3}$ & $\mathbf{4}$ & $\mathbf{5}$ & $\mathbf{6}$ & Household Numbers \\
\hline & & & & & & & \\
\hline & $\mathbf{0 . 0 0}$ & $\mathbf{0 . 0 0}$ & $\mathbf{+ 0 . 0 9}$ & $\mathbf{- 1 . 3 9}$ & $\mathbf{+ 1 . 5 2}$ & $\mathbf{0 . 0 0}$ & \\
\hline Illiterate & & & & & & & \\
\hline Literate (no formal education) & -2.52 & -0.18 & +0.14 & -1.88 & +2.02 & -0.50 & \\
\hline Primary (5 year) & -0.83 & -0.09 & +0.11 & -1.65 & +1.83 & -0.35 & \\
\hline Secondary & +0.24 & 0.00 & +0.10 & -1.73 & +1.90 & -0.08 & \\
\hline Secondary (vocational) & +0.04 & -0.01 & +0.10 & -1.53 & +1.68 & -0.01 & \\
\hline High & +0.51 & +0.07 & +0.05 & -1.29 & +1.46 & 0.00 & \\
\hline High (vocational) & -0.23 & +0.01 & +0.08 & -1.26 & +1.42 & +0.07 & \\
\hline University (two year) & +0.42 & +0.03 & +0.08 & -1.29 & +1.44 & +0.12 & \\
\hline University (4 year) & +0.17 & -0.04 & +0.08 & -1.11 & +1.15 & +0.09 & \\
\hline Master, PhD & +0.05 & +0.02 & +0.05 & -0.81 & +0.88 & +0.16 & \\
\hline
\end{tabular}


Table A5: Average Gains and Losses due to Tariff Changes Depending Upon Household Structure: Expenditure Gains (+); Losses (-) (1000000TL) p.a. (standard deviations in brackets)

\begin{tabular}{|c|c|c|c|c|c|c|c|c|c|c|c|c|}
\hline \multirow[b]{2}{*}{ Household Type } & \multicolumn{12}{|c|}{ Scenarios } \\
\hline & 1 & (SD1) & 2 & $(S D 2)$ & 3 & $(S D 3)$ & 4 & (SD4) & 5 & $(S D 5)$ & 6 & $(S D 6)$ \\
\hline$A L L$ & 0,00 & & 0.00 & & +3.60 & & -57.98 & & +63.47 & & 0.00 & \\
\hline Single adult ${ }^{\star}$ & +17.24 & $(0.95)$ & +1.44 & $(0.08)$ & +1.98 & $(0.31)$ & -40.23 & $(0.98)$ & +43.10 & $(1.12)$ & -10.06 & $(0.54)$ \\
\hline Single parent with children (18-) & +9.45 & (0.31) & -0.39 & $(0.01)$ & +3.07 & (0.22) & -46.85 & $(0.37)$ & +51.18 & (0.41) & -7.48 & $(0.24)$ \\
\hline $\begin{array}{l}\text { Single parent with children (one child } \\
18+)\end{array}$ & +4.04 & $(0.19)$ & 0.00 & $(0.00)$ & +3.35 & $(0.32)$ & -54.55 & $(0.16)$ & +58.59 & $(0.23)$ & -2.02 & $(0.08)$ \\
\hline Childless couple & +21.46 & $(2.12)$ & +1.34 & $(0.13)$ & +2.78 & $(0.63)$ & -51.86 & $(0.60)$ & +55.88 & $(0.75)$ & -3.13 & $(0.28)$ \\
\hline Parents with one child (18-) & +20.49 & $(1.87)$ & +2.10 & $(0.19)$ & +3.11 & $(0.61)$ & -58.33 & $(0.03)$ & +63.58 & $(0.01)$ & +1.58 & $(0.17)$ \\
\hline Parents with one child (18+) & +24.01 & $(1.65)$ & +1.85 & $(0.13)$ & +3.89 & $(0.51)$ & -63.71 & $(0.39)$ & +68.33 & (0.33) & +4.62 & (0.33) \\
\hline Parents with two children (18-) & +14.62 & $(1.58)$ & +1.12 & $(0.12)$ & +3.33 & $(0.75)$ & -58.10 & $(0.01)$ & +61.47 & $(0.22)$ & 0.00 & $(0.03)$ \\
\hline $\begin{array}{l}\text { Parents with two children (one child } \\
18+)\end{array}$ & +16.41 & $(1.17)$ & +1.73 & $(0.12)$ & +4.17 & $(0.55)$ & -66.49 & $(0.60)$ & +73.40 & $(0.71)$ & +6.91 & $(0.51)$ \\
\hline $\begin{array}{l}\text { Parents with three children or more } \\
(18-)\end{array}$ & -58.34 & $(4.86)$ & -3.14 & $(0.26)$ & +4.04 & $(0.64)$ & -53.95 & $(0.34)$ & +58.97 & $(0.38)$ & -5.65 & $(0.45)$ \\
\hline $\begin{array}{l}\text { Parents with three children or more } \\
\text { (at least one child 18+) }\end{array}$ & -66.17 & $(4.80)$ & -3.31 & $(0.24)$ & +4.81 & $(0.61)$ & -64.52 & $(0.47)$ & +69.48 & $(0.44)$ & +0.83 & $(0.08)$ \\
\hline Larger family ${ }^{\star \star}$ & +25.64 & $(1.06)$ & 0.00 & $(0.00)$ & +3.54 & $(0.29)$ & -61.54 & $(0.15)$ & +69.23 & $(0.24)$ & +2.56 & $(0.12)$ \\
\hline Larger family with children (18-) & -3.05 & $(0.23)$ & -3.05 & (0.23) & +4.17 & $(0.59)$ & -63.21 & $(0.40)$ & +68.55 & $(0.38)$ & +0.76 & (0.08) \\
\hline $\begin{array}{l}\text { Larger family with children (at least } \\
\text { one child } 18+\text { ) }\end{array}$ & -20.60 & $(1.53)$ & -3.17 & $(0.24)$ & +4.52 & $(0.60)$ & -67.35 & $(0.70)$ & +72.90 & $(0.70)$ & +3.17 & $(0.25)$ \\
\hline $\begin{array}{l}\begin{array}{l}\text { Individuals living in the same } \\
\text { house }^{\star \star \star}\end{array} \\
\end{array}$ & +10.42 & $(0.15)$ & +2.08 & $(0.03)$ & +2.81 & $(0.09)$ & -58.33 & $(0.01)$ & +62.50 & $(0.01)$ & 0.00 & $(0.00)$ \\
\hline Relatives living in the same house & +10.67 & (0.19) & +1.33 & $(0.02)$ & +3.07 & (0.12) & -54.67 & $(0.06)$ & +58.67 & (0.09) & -1.33 & $(0.02)$ \\
\hline
\end{tabular}

* Other parent away from house due to various reasons such as working in another city, or divorce, or death, etc.;

** Larger family consists of relatives of at least two generation living in the same house (grandparents, parents, aunt, uncle etc.);

*** Students, workers etc. 
Table A5a: Gains and Losses due to Tariff Changes Depending Upon Household Structure: Gains (+); Losses(-) \% of household disposable income

\begin{tabular}{|c|c|c|c|c|c|c|c|}
\hline \multirow[b]{2}{*}{ Household Type } & \multicolumn{6}{|c|}{ Scenarios } & \multirow[b]{2}{*}{ Household Numbers } \\
\hline & 1 & 2 & 3 & 4 & 5 & 6 & \\
\hline$A L L$ & 0.00 & 0.00 & +0.09 & -1.39 & +1.52 & 0.00 & 16385 \\
\hline Single adult* & +0.24 & +0.02 & +0.03 & -0.45 & +0.49 & -0.14 & 696 \\
\hline Single parent with children (18-) & +0.27 & -0.01 & +0.09 & -1.04 & +1.14 & -0.21 & 254 \\
\hline Single parent with children (one child 18+) & +0.10 & 0.00 & +0.08 & -1.03 & +1.10 & -0.05 & 495 \\
\hline Childless couple & +0.38 & +0.02 & +0.05 & -0.74 & +0.80 & -0.05 & 2237 \\
\hline Parents with one child (18-) & +0.39 & +0.03 & +0.06 & -0.90 & +0.98 & +0.03 & 1903 \\
\hline Parents with one child (18+) & +0.48 & +0.03 & +0.08 & -1.02 & +1.09 & +0.09 & 1083 \\
\hline Parents with two children (18-) & +0.38 & +0.02 & +0.09 & -1.19 & +1.26 & 0.00 & 2668 \\
\hline Parents with two children (one child 18+) & +0.38 & +0.03 & +0.10 & -1.22 & +1.34 & +0.16 & 1158 \\
\hline Parents with three children or more (18-) & -2.45 & -0.10 & +0.17 & -1.65 & +1.81 & -0.24 & 1594 \\
\hline Parents with three children or more (at least one child 18+) & -2.39 & -0.09 & +0.17 & -1.81 & +1.95 & +0.03 & 1209 \\
\hline Larger family ${ }^{\star \star}$ & +0.60 & 0.00 & +0.08 & -1.14 & +1.29 & +0.06 & 390 \\
\hline Larger family with children (18-) & -0.10 & -0.08 & +0.14 & -1.61 & +1.74 & +0.03 & 1313 \\
\hline Larger family with children (at least one child 18+) & -0.73 & -0.08 & +0.16 & -1.77 & +1.92 & +0.11 & 1262 \\
\hline Individuals living in the same house ${ }^{\star \star \star}$ & +0.13 & +0.03 & +0.04 & -0.72 & +0.77 & 0.00 & 48 \\
\hline Relatives living in the same house & +0.20 & +0.02 & +0.06 & -0.86 & +0.93 & -0.03 & 75 \\
\hline
\end{tabular}

Relatives living in the same house

(

* Larger family consists of relatives of at least two generation living in the same house (grandparents, parents, aunt, uncle etc.)

*** Students, workers etc. 
Table A6: Average Gains and Losses due to Tariff Changes Depending Upon Dwelling Ownership and Type: Expenditure Gains (+); Losses (-) (1000000TL) p.a. (standard deviations in brackets)

\begin{tabular}{|c|c|c|c|c|c|c|c|c|c|c|c|c|}
\hline & \multicolumn{12}{|c|}{ Scenarios } \\
\hline & 1 & (SD1) & 2 & (SD2) & 3 & (SD3) & 4 & (SD4) & 5 & (SD5) & 6 & (SD6) \\
\hline$A L L$ & 0,00 & & 0.00 & & +3.60 & & -57.98 & & +63.47 & & 0.00 & \\
\hline \multicolumn{13}{|l|}{ Dwelling Ownership } \\
\hline Household owned & +0.87 & $(0.42)$ & 0.00 & $(0.22)$ & +3.67 & (3.53) & -58.92 & $(0.46)$ & +64.99 & $(0.73)$ & -5.75 & (2.67) \\
\hline Tenant & +5.17 & $(1.45)$ & +2.59 & (0.29) & +3.28 & (1.93) & -54.31 & (1.03) & +62.06 & $(0.40)$ & +2.48 & $(0.76)$ \\
\hline Provided by employer & -125.49 & (9.04) & -7.84 & $(0.05)$ & +6.47 & $(0.73)$ & -66.67 & $(0.63)$ & +70.59 & $(0.51)$ & 0.00 & $(0.02)$ \\
\hline Other & +18.01 & $(2.18)$ & +4.16 & $(0.06)$ & +3.22 & (0.83) & -54.02 & $(0.48)$ & +59.56 & $(0.47)$ & -1.88 & $(0.20)$ \\
\hline \multicolumn{13}{|l|}{ Type of Dwelling } \\
\hline Detached House & -15.34 & $(5.00)$ & -3.84 & $(0.45)$ & +3.66 & (2.37) & -53.69 & $(1.40)$ & +55.61 & $(2.56)$ & +0.87 & $(0.36)$ \\
\hline $\begin{array}{l}\text { Semi-Detached and } \\
\text { Apartments }\end{array}$ & +5.60 & $(2.61)$ & +1.32 & $(0.68)$ & +3.54 & (3.34) & -61.10 & $(1.46)$ & +66.32 & (1.33) & 0.00 & $(0.11)$ \\
\hline Shanty House & +32.26 & (3.03) & +4.61 & $(0.04)$ & +4.42 & $(0.75)$ & -53.00 & $(0.47)$ & +55.30 & $(0.77)$ & -3.92 & $(0.35)$ \\
\hline Other & +20.00 & $(0.36)$ & +5.63 & $(0.00)$ & +2.44 & $(0.11)$ & -46.88 & $(0.20)$ & +50.63 & $(0.23)$ & +1.39 & $(0.03)$ \\
\hline
\end{tabular}


TableA6a: Gains and Losses due to Tariff Changes Depending Upon Dwelling Ownership and Type: Gains (+); Losses (-) \% of household disposable income

\begin{tabular}{|c|c|c|c|c|c|c|c|}
\hline & \multicolumn{6}{|c|}{ Scenarios } & \multirow[b]{2}{*}{ Household Numbers } \\
\hline & 1 & 2 & 3 & 4 & 5 & 6 & \\
\hline$A L L$ & 0,00 & -1.39 & 0.00 & 0.00 & +0.09 & -0.67 & 16385 \\
\hline Household owned & +0.02 & -1.07 & 0.00 & -0.20 & +0.09 & -0.65 & 11541 \\
\hline Tenant & +0.14 & -1.18 & +0.06 & +0.05 & +0.09 & -0.54 & 3867 \\
\hline \multicolumn{8}{|l|}{ Type of Dwelling } \\
\hline Detached House & -0.54 & -1.27 & -0.09 & +0.02 & +0.13 & -1.49 & 5215 \\
\hline Semi-Detached and Apartments & +0.11 & -1.04 & +0.02 & 0.00 & +0.07 & -0.48 & 10720 \\
\hline Shanty House & +1.22 & -1.51 & +0.13 & -0.08 & +0.17 & +0.35 & 434 \\
\hline
\end{tabular}

